\title{
Reproductive biology of the Amazon Lava Lizard (Tropidurus torquatus) from the Wet Chaco of Corrientes (Argentina): congeneric comparisons of ecotypic and interspecific variations
}

\author{
M.A. Ortiz, J.M. Boretto, C. Piantoni, B.B. Álvarez, and N.R. Ibargüengoytía
}

\begin{abstract}
Herein we describe the reproductive biology of a population of the Amazon Lava Lizard (Tropidurus torquatus (Wied-Neuwied, 1820)) from Corrientes, northeastern Argentina (Wet Chaco). We describe the male and female reproductive cycles, minimum body size for adults, reproductive output, mean relative clutch mass, fat body cycles, and sexual dimorphism. Our results were compared with data on the reproductive biology of Brazilian populations of T. torquatus and congeneric species. In Corrientes, males of $T$. torquatus exhibited a continuous reproductive cycle, but with annual variation of testicular parameters associated with spermatogenic activity. In contrast, females were reproductive only from winter to summer (July-February), laying at least two clutches each of six eggs, on average, per reproductive season. The relative clutch mass and egg size values in Corrientes were the highest reported for the species. The annual cycle of energy storage (as fat bodies) was inversely correlated with reproductive activity in both sexes. Males differed from females in snout-vent length, head size, interlimb length, and tail length. We observed interpopulational differences in relative clutch mass, egg volume and mass, incubation period and hatching time, and the minimum body size for sexual maturity probably as a result of phenotypic plasticity or adaptation to local environmental conditions and likely both.
\end{abstract}

Key words: reproductive cycle, Squamata, tropidurid, lizard, Tropidurus torquatus.

Résumé : Nous décrivons la biologie de la reproduction d'une population de lézards Tropidurus torquatus (Wied-Neuwied, 1820) de Corrientes, dans le nord-est de l'Argentine (Chaco humide). Nous décrivons les cycles de reproduction des mâles et des femelles, la taille minimum du corps des adultes, l'efficacité de la reproduction, la masse moyenne relative des pontes, les cycles des corps adipeux et le dimorphisme sexuel. Nos résultats sont comparés à des données relatives à la biologie de la reproduction de populations brésiliennes de T. torquatus et d'espèces congénères. À Corrientes, les mâles de T. torquatus présentent un cycle de reproduction continu, mais des variations annuelles des paramètres testiculaires associés à la spermatogénèse. En revanche, les femelles ne sont reproductives que de l'hiver à l'été (de juillet à février), produisant aux moins deux pontes de six œufs chacune en moyenne chaque saison de reproduction. Les valeurs de la masse relative des pontes et de la taille des œufs à Corrientes étaient les plus importantes signalées pour l'espèce. Le cycle annuel de stockage d'énergie (sous forme de corps adipeux) était inversement corrélé à l'activité de reproduction pour les deux sexes. Les mâles se distinguaient des femelles sur le plan de la longueur museau-cloaque, de la taille de la tête, de la longueur entre les membres et de la longueur de la queue. Nous avons observé des différences entre populations en ce qui concerne la masse relative des pontes, le volume et la masse des œufs, la période d'incubation et le moment de l'éclosion, ainsi que la taille minimum du corps à maturité sexuelle, ces différences étant probablement dues à la plasticité phénotypique, à l'adaptation à des conditions ambiantes locales ou, vraisemblablement, à une combinaison de ces deux phénomènes. [Traduit par la Rédaction]

Mots-clés : cycle de reproduction, squamates, tropiduridés, lézard, Tropidurus torquatus.

\section{Introduction}

The timing of the reproductive cycles and the determination of the biotic and abiotic factors that affect them is critical in reproductive ecology (James and Shine 1985; Brown and Shine 2006). Numerous studies on both tropical and temperate species have demonstrated a correlation between the reproductive cycles and environmental parameters, such as temperature, photoperiod, and rainfall (Licht 1971, 1973; Marion 1982; Rocha 1992; Watling et al. 2005; Ferreira et al. 2011). Nevertheless, in tropical reptiles, a large variability in the reproductive cycles has been registered in different species from the same region (Duellman 1978; Fitch 1982; Dixon and Soini 1986), even under identical environmental conditions (Barbault 1976; Vitt and Goldberg 1983; Vitt 1992). This variability within populations suggests that other factors, such as the availability of nest sites (James and Shine 1985) and food (Ballinger 1977; Vitt et al. 1978; Dunham 1978, 1982) or differences in risk of mortality, can influence reproductive cycles. For example, incubation requires optimal thermal and hydric conditions

Received 2 January 2014. Accepted 14 May 2014.

M.A. Ortiz and B.B. Álvarez. Laboratorio de Herpetología, Facultad de Ciencias Exacta y Naturales y Agrimensura, Universidad Nacional del Nordeste, Avenida Libertad 5460, 3400, Corrientes, Argentina.

J.M. Boretto and N.R. Ibargüengoytía. INIBIOMA (CONICET - Universidad Nacional del Comahue), San Carlos de Bariloche, 8400, Río Negro, Argentina. C. Piantoni. Departamento de Fisiologia, Instituto de Biosciências, Universidade de São Paulo, Rua do Matão, TR 14, no. 321, Cidade Universitária, 05508-900, São Paulo, SP, Brazil.

Corresponding author: Martín A. Ortiz (e-mail: maortiz143@gmail.com). 
for successful hatching (Brown and Shine 2006) and gonadal development requires sufficient and timely lipid storage (e.g., Magnusson 1987; Ramírez-Pinilla 1995; Wiederhecker et al. 2002; Galdino et al. 2003). In addition, reproductive phenotypes evolve as responses to foraging and escape strategies (Vitt and Congdon 1978; Vitt and Price 1982), body size and shape (Vitt 1981; Vitt and Goldberg 1983; Vitt et al. 1997), and phylogenetic inertia (Stearns 1984; Dunham and Miles 1985; Dunham et al. 1988; Vitt 1992; Mesquita and Colli 2010).

The genus Tropidurus Wied-Neuwied, 1824 is widespread in South America, occurring east of the Andes from southern Venezuela to the center of Argentina (Rodrigues 1987, 1988; Cei 1993). It comprises 26 species of oviparous lizards (Uetz and Hošek 2013) that occupy a wide range of habitats, including wet and dry forests and savannas (Vitt 1993; Vitt and Zani 1996; Cruz et al. 1998; Wiederhecker et al. 2003). Females usually lay multiple clutches per year. Different reproductive patterns have been described for the genus, varying from continuous reproduction in Peters' Lava Lizard (Tropidurus hispidus) in the Caatinga (Vitt and Goldberg 1983) and in the Amazon Lava Lizard (Tropidurus torquatus) in the Atlantic Forest (Teixeira and Giovanelli 1999), to seasonal patterns with variation in the length of the reproductive season. For example, in the Spiny Lava Lizard (Tropidurus spinulosus) and Etheridge's Lava Lizard (Tropidurus etheridgei) that inhabit the Dry Chaco in Salta, Argentina, the reproductive season lasts 3 months (NovemberJanuary; Cruz 1997) and 6 months (September-February; Cruz et al. 1997), respectively. In Brazilian biomes, Tropidurus itambere from the Atlantic Forest has a reproductive season of 7 months (September-March; Van Sluys 1993), and a similar cycle is exhibited in a population of T. torquatus from the Cerrado (AugustFebruary; Wiederhecker et al. 2002) and the Striped Lava Lizard (Tropidurus semitaeniatus) from the Caatinga (July-January; Vitt and Goldberg 1983). However, Arruda (2009) documented that the reproductive season of $T$. torquatus in the Brazilian Pampa lasts 5 months (September-January), and recently Ribeiro et al. (2012) have recorded a reproductive cycle of 5-6 months (NovemberMarch, April) for T. semitaeniatus from the Brazilian Caatinga. This high variation in the timing and duration of the reproductive season suggests that environmental factors contribute to such variation (Van Sluys et al. 2010).

Tropidurus torquatus is one of the most widely distributed species of the genus, occupying open and rocky habitats with scarce vegetation from central-southeastern Brazil, to northern Argentina, Uruguay, and Paraguay (Rodrigues 1987; Cei 1993; Carreira et al. 2005). It is a medium-sized, territorial, and polygynous lizard with a sit-and-wait, mainly insectivorous, predatory behaviour (Álvarez et al. 1985; Bergallo and Rocha 1993; Kohlsdorf et al. 2006; Ribeiro et al. 2008). The reproductive biology of T. torquatus populations from different Brazilian biomes has been thoroughly studied (Wiederhecker et al. 2002; Kiefer et al. 2008; Van Sluys et al. 2010; Brandt and Navas 2011; Winck and Rocha 2012). However, despite being a relatively common lizard inhabiting Argentinian biomes, there is a lack of study on their reproductive biology.

Herein, we describe cycles in reproduction and the presence of fat bodies in T. torquatus from the province of Corrientes, northeastern Argentina, Eastern District of the Chaco phytogeographic province. We present data on the minimum body size of adults, reproductive output, and mean relative clutch mass, and address the following questions. (1) Is the timing of gametogenesis correlated with climate? (2) Are male and female reproductive cycles synchronous? (3) How does the timing of lipid storage relate to gametogenesis and embryonic development? (4) Is there sexual dimorphism, and if so, what are the likely causes? Finally, the reproductive cycles of male and female $T$. torquatus from Wet Chaco in Argentina are compared with that of T. torquatus and congeneric species from Brazil, in relation to climate and other environmental factors.

\section{Materials and methods}

\section{Study area}

The study was conducted in the Capital Department of Corrientes province $\left(27^{\circ} 25^{\prime} 50^{\prime \prime} \mathrm{S}, 58^{\circ} 44^{\prime} 48^{\prime \prime} \mathrm{W}\right)$, Argentina, part of the Eastern District of the Chaco phytogeographic province (Cabrera and Willink 1980). This phytogeographical region consists of a wide variety of vegetation formations, including woodlands, rainforests, savannas, prairies, scrublands, grasslands, and palm groves with aquatic and marshland vegetations. The climate is generally warm and subtropical; there is no dry season, although rainfall in winter is significantly lower (June-September), particularly in July and August when the historical means are lower than $50 \mathrm{~mm}$. The mean annual rainfall in the region is $1200 \mathrm{~mm}$. The mean annual temperature is $21.5^{\circ} \mathrm{C}$, ranging from $15^{\circ} \mathrm{C}$ in July to $26.5-27^{\circ} \mathrm{C}$ in January (Carnevali 1994; Bruniard 1997). Frosts have been registered, but they are not common (Carnevali 1994). Mean temperature, photoperiod, relative humidity, and rainfall registered in the periods 1990-2007 and 2007-2009 were provided by the Servicio Meteorológico Nacional Argentino and the Servicio de Hidrografia Naval Argentino (Figs. 1A, 1B).

\section{Sampling and laboratory methods}

Sixty-five males and 74 females were hand-collected using rubber bands at monthly intervals, from December 2007 to December 2009. Lizards were sexed, weighed (BM) to the nearest $0.01 \mathrm{~g}$ with a digital balance (Ohaus ${ }^{\circledR}$ traveler scale TA320), and dimensions measured to the nearest $0.01 \mathrm{~mm}$ using a digital caliper (Essex®). To study sexual dimorphism, we measured snout-vent length (SVL), head length (HL), head width (HW), head height (HH), neck width (NW), distance between front and hind limbs (interlimb length, IL; sensu Olsson et al. 2002), diameter of the front leg (FLD) and hind leg (HLD) at the insertion to the shoulders and pelvic girdles, respectively, tail width immediately posterior to vent (TWV), tail length (TaL), and status of the tail (ST; intact, cut, or regenerated). Specimens were then euthanized by intraperitoneal administration of anesthesia (carticaine L-adrenaline) and testes and ovaries were dissected and measured. Testes were also weighed. After fixation in formalin for a period of $24 \mathrm{~h}$, the lizards were stored in $70 \%$ ethanol and incorporated to the herpetological collection of the Universidad Nacional del Nordeste (UNNE), Corrientes province, for future studies. One juvenile and four adult females from the UNNE collection, collected in February 1994 (UNNEC: 1650), August 1998 (UNNEC: 6269), and NovemberDecember 1999 (UNNEC: 6819, 6831, 6878), were also examined in this study to increase the number of ovigerous females and to better estimate the mean and variation of clutch size, as well as its relationship with SVL.

\section{Male reproductive cycle}

The male gonadal cycle was studied based on macro- and microscopical observations. Testes were removed, weighed (TM) to the nearest $0.01 \mathrm{~g}$ using a digital scale, and then measured in length (TL) and width (TW) to the nearest $0.1 \mathrm{~mm}$ using a digital caliper. Testis volume (TV) was calculated as $V=(4 / 3) \pi(\mathrm{TL} / 2)(\mathrm{TW} / 2)^{2}$.

The microscopical activity of the gonads was investigated using conventional histological techniques. Arbitrarily, the left testis and epididymis were removed from each male after euthanasia, fixed in Bouin's solution or $10 \%$ formalin for $24 \mathrm{~h}$, and preserved in $70 \%$ ethanol. Gonads were then dehydrated in an ethanol series and embedded in paraffin for $24 \mathrm{~h}$ at $52{ }^{\circ} \mathrm{C}$. Subsequently, the material was cut with a microtome Reichert-Jung Hn40 in sections of $5 \mu \mathrm{m}$ and stained with hematoxiline and eosine.

Spermatogenic stages were determined based on the most advanced cell type present in the seminiferous tubules, following Mayhew and Wright (1970), and cell types were recognized based on Gribbins et al. (2006) and Uribe (2002). Five spermatogenic stages were observed as follows: (I) only spermatogonia, (II) primary and 
Fig. 1. Monthly means of climatic variables in Corrientes, Argentina. (A) Temperature (solid circles) and photoperiod (open triangles); (B) rainfall (solid squares), air humidity (inverted open triangles) from December 2007 through December 2009, and rainfall from January 1990 through December 2007 (open squares). Climatic data from Servicio Meteorológico Nacional and Servicio de Hidrografía Naval.
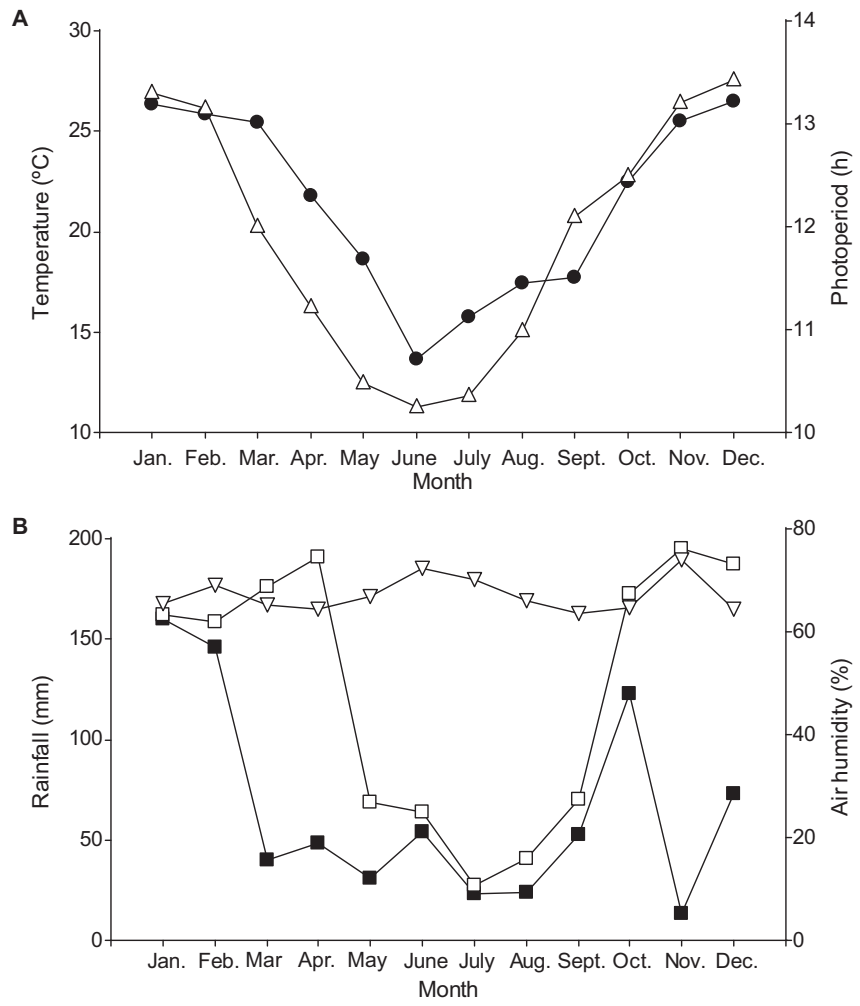

secondary spermatocytes, (III) round spermatids and in the process of elongation, (IV) spermatozoa in the seminiferous tubules, and (V) initial regression with cellular debris and scarce spermatozoa in tubular lumen (modified from Mayhew and Wright 1970). The presence or absence of spermatozoa in the epididymis was also registered. Minimum SVL at sexual maturity in males was determined based on the smallest specimen with spermatogenic activity (stages II-V) or spermatozoa in the epididymis.

\section{Female reproductive cycle}

Female gonadal cycles were defined by the presence and number of vitellogenic follicles, oviductal eggs, and corpora lutea. The follicle size was estimated as the diameter of the largest follicle for each female (Ibargüengoytía and Cussac 1998) and was measured with an ocular micrometer to the nearest $0.1 \mathrm{~mm}$ using an Olympus ${ }^{\circledR}$ SZX9 stereoscopic microscope. The largest and smallest diameter of each oviductal eggs were measured with a digital caliper to the nearest $0.1 \mathrm{~mm}$ to further calculate their volume with the equation of a spheroid mentioned above for males. Minimum SVL at sexual maturity for females was estimated based on the smallest female containing enlarged vitellogenic follicles, oviductal eggs, or corpora lutea. The simultaneous presence of vitellogenic follicles and oviductal eggs, or vitellogenic follicles and corpora lutea, was considered indicative of the occurrence of more than one clutch per reproductive season. Females without vitellogenic follicles and oviducts with either an absence of folds or a presence of small folds were classified as juveniles. This method follows the definition of Ibargüengoytía and Cussac (1998): "Uterus type 1: folds, if present, are small, and never spread over the entire uterus."
Clutch size was the number of oviductal eggs. Reproductive investment was estimated using the relative clutch mass (RCM). RCM index was calculated following two methods: (1) RCMinc = $\mathrm{CM} / \mathrm{FBM}$, where CM is clutch mass and FBM is the female's body mass (which includes the clutch mass), and (2) RCMexc $=\mathrm{CM}$ / (FBM - CM), where the clutch mass is subtracted from the female's body mass (Shine 1980; Rodríguez-Romero et al. 2005; Kiefer et al. 2008).

The relationship between clutch size and egg volume was determined by a partial correlation analysis, eliminating the effect of maternal body size using female SVL as the covariate (Ford and Seigel 1989, 2006). The minimum time required to produce one clutch was estimated as the period of time between the first female captured that presented vitellogenic follicles and the first female captured that showed corpora lutea (Huang 1998; Galdino et al. 2003). Additionally, the incubation time was estimated as the period of time between the first female captured with corpora lutea and the first field observation of juveniles (Wiederhecker et al. 2002).

\section{Operational sex ratio}

The operational sex ratio (OSR) of reproductive and sexually receptive males to females was calculated considering only males with spermatogenic activity (stages II-IV) and females with vitellogenic follicles, including those presenting vitellogenic follicles and oviductal eggs or vitellogenic follicles and corpora lutea simultaneously.

\section{Sexual dimorphism}

Morphometrical descriptions for the assessment of sexual dimorphism of T. torquatus were restricted to adults and were made using SVL, BM, HL, HW, HH, NW, IL, FLD, HLD, TWV, TaL, and ST. First, we performed a nonparametric Mann-Whitney $U$ test for two-independent samples to determine the statistical significance of the difference between female and male SVLs. Then, the morphological variables (BM, HL, HW, HH, NW, IL, FLD, HLD, and TWV; each transformed to natural logarithms) were regressed on natural logarithms of SVL to generate residuals for further analysis. Stepwise discriminant analysis (based on $P$ value with $\alpha=0.05$ and $\alpha=0.10$ as input and output significance levels, respectively) was used to determine the variables that better explain the differences between the sexes. Analysis of covariance (ANCOVA) (SVL is the covariate) was used to test the sexual dimorphism in tail length (TaL; only the specimens with intact tails were considered). To set up the possible causes of intersexual differences in the frequency of caudal autotomy, a $\chi^{2}$ test was performed to compare intact versus cut or regenerated tails between males and females.

\section{Fat body cycles}

Fat bodies were excised after necropsy of each lizard, fixed in $10 \%$ formaldehyde, and weighed to the nearest $0.001 \mathrm{~g}$ using the analytical balance Sartorius ${ }^{\circledR}$ AZ-214. Residuals of the linear regression between fat body mass and SVL were used.

\section{Statistical analyses}

Statistical analyses were conducted using INFOSTAT (2011 version), SPSS (version 17.0), and SIGMAPLOT (version 10.0). The data were transformed to natural logarithms (ln) and square roots when necessary to reach the normality and homogeneity of variance assumptions for parametric tests (Zuur et al. 2010). The assumption of normality was checked with the Shapiro-Wilk's tests and Levene's homogeneity of variance test. When normality or homogeneity of variance was not met, nonparametric equivalents such as the Mann-Whitney $U$ test were used. The Di Rienzo, Guzmán, and Casanoves (DGC) method was used for multiple comparisons (Di Rienzo et al. 2002). Dependence between variables was tested performing simple and multiple regressions (bidirectional stepwise elimination based on $P$ value and significance lev- 
Fig. 2. Box plots of the significant dimorphic traits $(P<0.05)$ of female and male Amazon Lava Lizards (Tropidurus torquatus).
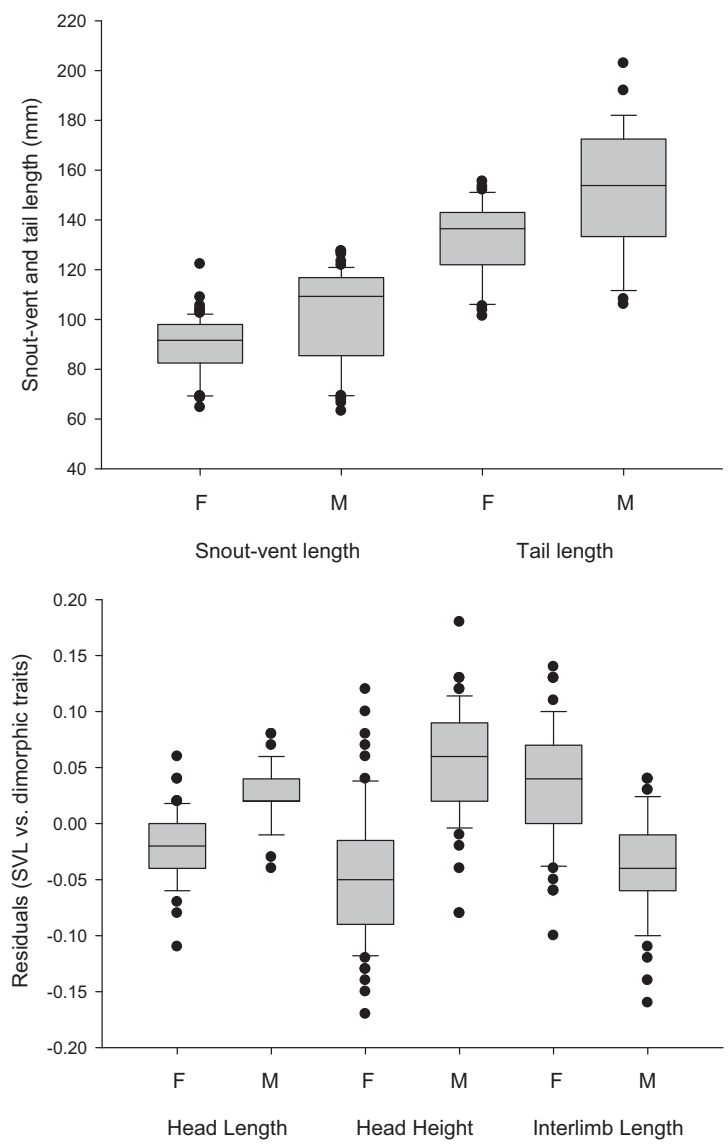

els for testing input and output variables were $\alpha=0.05$ and $\alpha=$ 0.10 , respectively), as well as correlations. When correlation between independent variables and SVL was found, an ANCOVA was performed using SVL as the covariate (Guisande et al. 2006), or residuals of the linear regression were used (Ramírez-Bautista and Vitt 1997) to perform further analysis.

The significance level used was $P<0.05$ for all statistical tests. Results are presented as means \pm standard deviations (SD) unless otherwise indicated.

\section{Results}

\section{Body size and sexual maturity}

Minimum adult size for males was $63.2 \mathrm{~mm}$ SVL, with maturity defined by the presence of round or elongated spermatids (stage III). In females, the minimum adult size was $64.6 \mathrm{~mm}$ SVL, with adults having vitellogenic follicles. Adult males ranged from 63.2 to $127.5 \mathrm{~mm}$ SVL $(101.2 \pm 18.9 \mathrm{~mm}, n=55)$ and from 7.69 to $75.09 \mathrm{~g}$ of body mass ( $40.89 \pm 20.45 \mathrm{~g}, n=55)$, while adult females ranged from 64.6 to $122.2 \mathrm{~mm} \mathrm{SVL}(89.7 \pm 11.9 \mathrm{~mm}, n=61)$ and from 7.96 to $55.97 \mathrm{~g}$ of body mass $(24.11 \pm 9.22 \mathrm{~g}, n=61)$. Juvenile males ranged from 31.1 to $60.0 \mathrm{~mm}$ SVL $(44.6 \pm 9.2 \mathrm{~mm}, n=10)$ and from 0.77 to $7.70 \mathrm{~g}$ of body mass ( $3.05 \pm 2.04 \mathrm{~g}, n=10)$, while juvenile females ranged from 34.9 to $64.3 \mathrm{~mm}$ SVL $(49.7 \pm 11.3 \mathrm{~mm}, n=14)$ and from 0.85 to $8.00 \mathrm{~g}$ of body mass $(4.56 \pm 2.78 \mathrm{~g}, n=13)$.

\section{Sexual dimorphism}

Adult male SVL was larger than that of adult females (MannWhitney $U$ test, $U=3911, P<0.001, n=116$ ), and males also had longer tails (TaL; ANCOVA with SVL as the covariate, $F_{[1,55]}=8.18$, $P=0.006, n=58$ ) and longer and higher heads (HL and HH, respectively; discriminant analysis, $\lambda=0.366, \chi_{[3]}^{2}=113.0, P<0.001$,
Fig. 3. Male reproductive cycle of the Amazon Lava Lizard (Tropidurus torquatus). Percentages are presented for each spermatogenic stage: (I) only spermatogonia; (II) primary and secondary spermatocytes; (III) spermatids; (IV) spermatozoa in the tubule; and (V) cellular debris characteristic of testicular regression, with few spermatozoa.

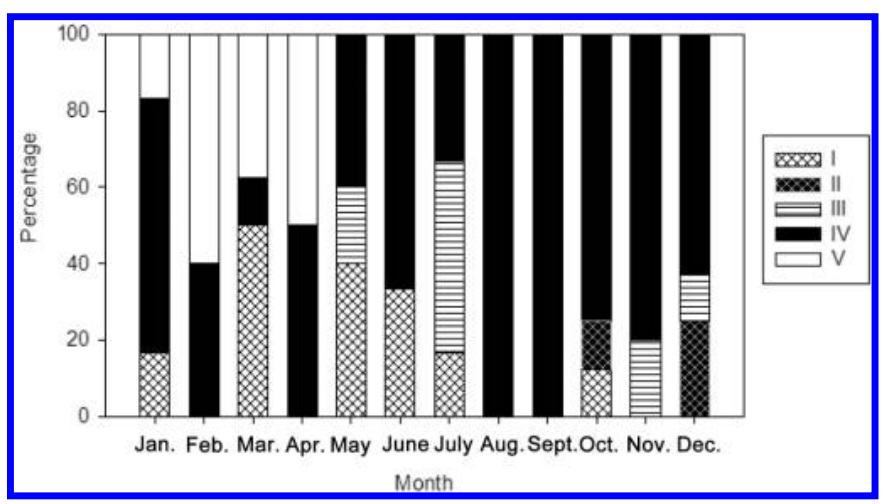

$n=116$; Fig. 2), while females exhibited a larger distance between front and hind limbs (IL). Adult males and females did not show differences in the frequency of caudal autotomy $\left(\chi_{[1]}^{2}=\right.$ $0.03, P=0.852, n=116)$. Cut and regenerated tails were recorded in $51 \%$ of the males and in $49 \%$ of the females.

In addition, males with intact tails did not show any difference in body size or body mass compared with males with cut or regenerated tails (SVL: Mann-Whitney $U$ test, $U=701.0, P=0.354$; body mass: $U=705.0, P=0.390)$; females also did not show any difference (SVL: $U=977.5, P=0.493$; body mass: $U=943.5, P=0.845$ ).

\section{Male reproductive cycle}

Young males were collected (stage I, $n=10$ ) from mid-summer (January) to early spring (October; Fig. 3). Males with primary and secondary spermatocytes (stage II, $n=3$ ) were collected in early spring (October) and early summer (December), and males with round and elongated spermatids (stage III, $n=6$ ) were found from mid-autumn (May) to early summer (December). Males with spermatozoa in the seminiferous tubules (stage IV, $n=38$ ) were captured throughout the year, while testicular regression (stage V, $n=8$ ) was only recorded in males captured from early summer (January) to early autumn (April; Fig. 3). Only five males with testes in stage IV did not show spermatozoa in the epididymis.

There was a positive relationship between SVL and testicular mass (TM) and between SVL and testicular volume (TV) (simple linear regression; SVL vs. TM: $r^{2}=0.51, F_{[1,51]}=53.40$, slope $=3.61 \pm$ $0.49, P<0.001$; SVL vs. TV: $r^{2}=0.51$, slope $=3.57 \pm 0.49, F_{[1,53]}=$ 53.27, $P<0.001)$. The adjusted means of testicular mass and volume showed a similar annual variation with lower values from late spring (December) to early autumn (April; Figs. 4A, 4B), a time when testicular regression was recorded (Fig. 3). The highest mean values of testicular mass and volume were registered from midwinter (August) to mid-spring (November), when a high percentage of males (80\%-100\%) exhibited spermatogenic stage IV.

Males larger than $80 \mathrm{~mm}$ SVL showed spermiation (spermatogenic stage IV) throughout the year, while adult males smaller than $80 \mathrm{~mm}$ SVL exhibited spermatogenic stage IV only from July onward (Fig. 5).

Significant differences among spermatogenic stages were observed in mean testicular volume and mass (ANCOVA; TV: $\mathrm{F}_{[3,50]}=$ 11.31, $P<0.001, n=55$; TM: $\left.F_{[3,48]}=12.22, P<0.001, n=53\right)$. The highest mean values of these testicular parameters (TV and TM) were registered at stage IV and were significantly different from the rest of the stages (Fig. 6).

Climatic cues such as temperature, photoperiod, relative humidity, and rainfall showed no relation to the testicular parameters 
Fig. 4. Adjusted monthly means and standard error of the (A) testicular mass (g) and (B) testicular volume $\left(\mathrm{mm}^{3}\right)$ for adult Amazon Lava Lizards (Tropidurus torquatus). Cycles of testicular parameters are depicted as residuals from snout-vent length versus testicular volume and mass regressions.
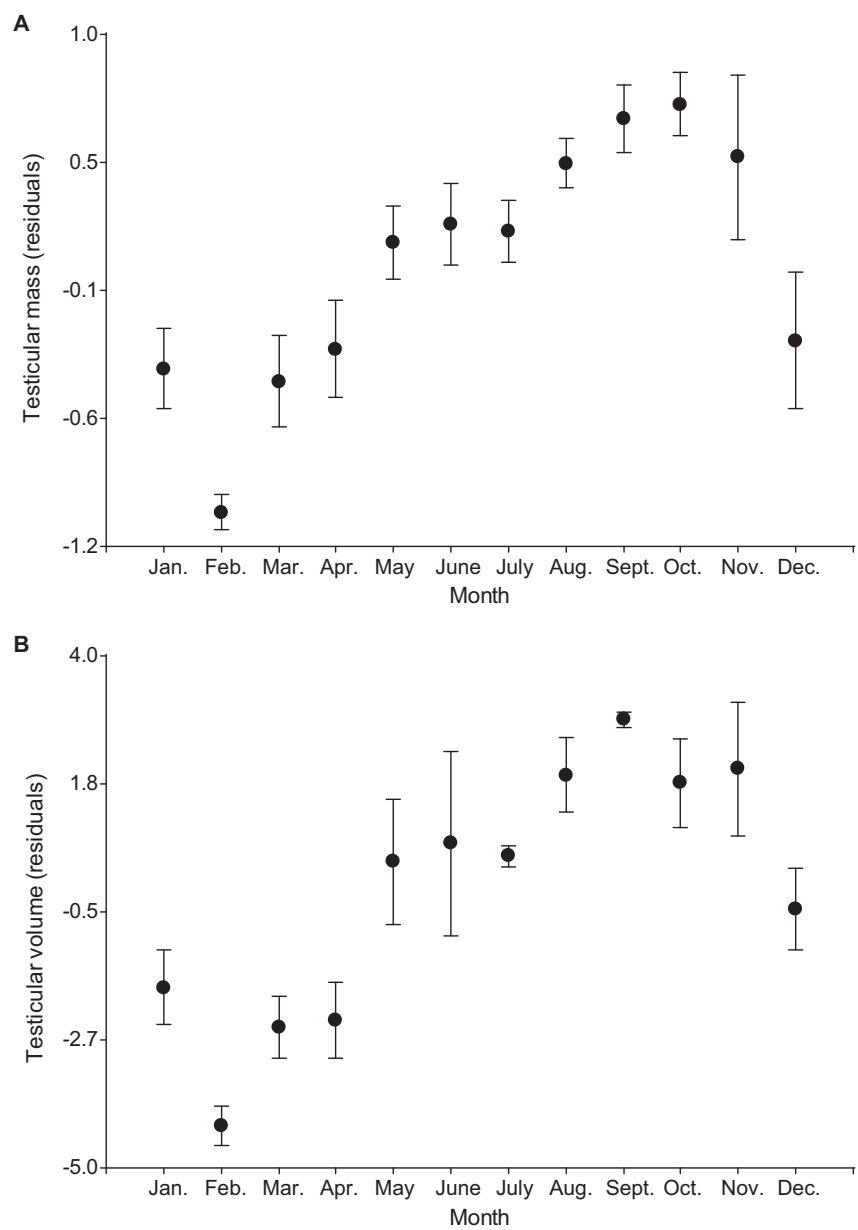

(multiple stepwise regression; TV: $F_{[6,11]}=2.34, P=0.165$; TM: $\left.F_{[6,11]}=1.89, P=0.229\right)$.

\section{Follicular size and female reproductive cycle}

Adult females exhibited follicular growth from early winter (July), when vitellogenesis starts, until early summer (January; Fig. 7). Stepwise multiple regressions showed a significant relationship between follicular size and photoperiod (standardized coefficient $=0.93$ ), and between follicular size and rainfall (standardized coefficient $=-0.56$ ), between 2007 and 2009. These two climatic variables explained $85 \%$ of the variation in the follicular size $\left(F_{[2,4]}=11.67, P=0.021\right)$ during the reproductive season. The simultaneous presence of vitellogenic follicles and oviductal eggs, or vitellogenic follicles and corpora lutea, were observed from late winter (September) to early summer (January), indicating the production of at least two clutches per reproductive season (multiple clutches; Fig. 7). These simultaneous reproductive events were recorded only in females with a minimum SVL of $73 \mathrm{~mm}$ (Fig. 8). From mid-summer (February) to late autumn (June), only nonreproductive adult females were collected, although in early summer (January), one female was collected with large vitellogenic follicles (greatest follicle size $=10.4 \mathrm{~mm}$; Fig. 7). Only the largest adult female (122.2 mm SVL) exhibited signs of senescence, with very small ovaries, and a uterus morphologically similar to that of the juvenile females.

\section{Embryonic development, incubation, and births}

The first female with vitellogenic follicles was captured in early winter (July), while the first female with corpora lutea was collected in early spring (October; Fig. 7). This result points out that the minimum time elapsed between vitellogenesis and postures is 3 months. Juveniles showing umbilical scars were captured from mid-summer (ending January) to early winter (July) and their body sizes ranged from 31 to $40 \mathrm{~mm}$ SVL. The period of time between the capture of females with corpora lutea and the observations of juveniles with umbilical scars in the field indicates a minimum time elapsed from postures to egg eclosion as 3 months. The reproductive activity of small adult females (approximately 65$80 \mathrm{~mm} \mathrm{SVL}$ ) starts later in the season and they laid their eggs at the end of the breeding season (December; Fig. 8).

\section{Clutch size and female reproductive investment}

Clutch size varied from 4 to 9 eggs $(6.3 \pm 1.5, n=11)$ and was positively correlated with female SVL (Pearson's correlation, $r=$ $0.88, P<0.001, n=11$; Fig. 9$)$ and also with female mass $(r=0.95$, $P<0.001, n=11)$. The volume of individual eggs was $992.7 \pm$ $87.2 \mathrm{~mm}^{3}(n=11)$ and showed no relationship with female SVL $(r=$ $0.21, P=0.53, n=11$; Fig. 10$)$ nor with female mass $(r=0.27, P=0.43$, $n=11)$. The fresh total clutch mass was $0.92 \pm 0.15 \mathrm{~g}(n=6)$ and the fresh egg mass was $0.89 \pm 0.17 \mathrm{~g}(n=40)$. No relationship was found between egg volume and clutch size (Pearson's correlation, $r=$ $0.36, P=0.28, n=11)$. Even after considering the effect of female SVL, the relationship between egg volume and clutch size was not significant (partial correlation, $r=0.47, P=0.148, n=11$ ). We also did not find any relationship between these two variables taking into account the female body mass as a covariable (partial correlation, $r=0.35, P=0.292, n=11)$. The analysis of the reproductive investment showed that RCMinc ranged from 0.16 to $0.26(0.22 \pm$ $0.04, n=6)$ and RCMexc ranged from 0.18 to $0.35(0.28 \pm 0.06, n=6)$.

\section{Operational sex ratio}

A total of 55 adult males and 61 adult females were captured during the period 2007-2009. But, when considering only receptive adults, the OSR was 47 males to 31 females and was not different (binomial test, $P>0.089, n=78$ ). The OSR was $0.6 / 0.4$, i.e., 1.5 receptive males per available female.

\section{Fat body cycles}

Fat body mass in both adult females and adult males related to SVL (Spearman's correlation; males: $r_{\mathrm{S}}=0.67, P<0.001, n=55$; females: $\left.r_{\mathrm{S}}=0.51, P<0.001, n=61\right)$. Adjusted mean values of fat body mass varied monthly, in both males (ANOVA: $F_{[11,43]}=4.54, P<0.001$ ) and females (ANOVA: $F_{[11,48]}=6.98, P<0.001$ ), and were inversely correlated with the adjusted testicular volume $\left(r_{\mathrm{S}}=-0.69, \mathrm{P}<0.001\right)$ and follicular sizes $\left(r_{\mathrm{S}}=-0.57, \mathrm{P}<0.001\right.$; Figs. 11A, 11B).

\section{Discussion}

Asynchrony in gonadal activity between genders is common and is usually associated with sperm storage and differences in the duration of sexual receptivity (e.g., Flemming 1993; Méndez-de la Cruz et al. 1998; Ibargüengoytía 2008; Mouton et al. 2012). Although testicular volume and mass varies seasonally, males have epididymal spermatozoa and can mate throughout the year, while females reproduce mainly during the wet season, a common pattern in tropical reptiles (Wilhoft 1963; Clerke and Alford 1993; Van Sluys 1993; Wiederhecker et al. 2002). More unusual, however, is individual variation of gonadal activity within genders as shown by male T. torquatus from Corrientes.

The continuity of male sexual receptivity and function could be interpreted as an adaptation to asynchrony among females, because females shorter than $80 \mathrm{~mm}$ SVL start vitellogenesis at least 2 months later than larger females. This temporal segregation could correspond to a cyclical and seasonal variation in the structure of the population as seen in populations from the Cerrado 
Fig. 5. Male body size distribution (snout-vent length) in the Amazon Lava Lizard (Tropidurus torquatus) based on the spermatogenic stages throughout the year: (I) seminiferous tubules (ST) with spermatogonia (open circles); (II) ST with primary and secondary spermatocytes (open squares); (III) ST with round spermatids in the process of elongation (open triangles); (IV) ST with spermatozoa in the tubule (solid circles); (V) testes in early regression (asterisks).

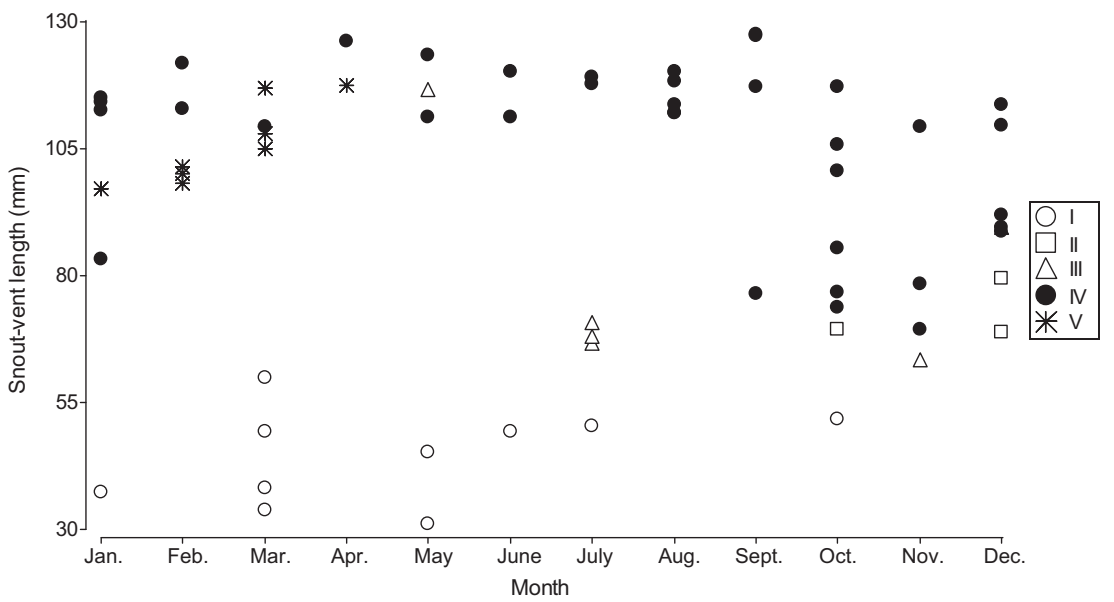

Fig. 6. Adjusted means and standard error of testicular volume (open circles) and testicular mass (solid circles) versus the spermatogenic stages of adult Amazon Lava Lizards (Tropidurus torquatus): (II) spermatocytes; (III) spermatids; (IV) spermatozoa; (V) early regression. Different letters indicate significant differences (DGC method, $P<0.05$ ).

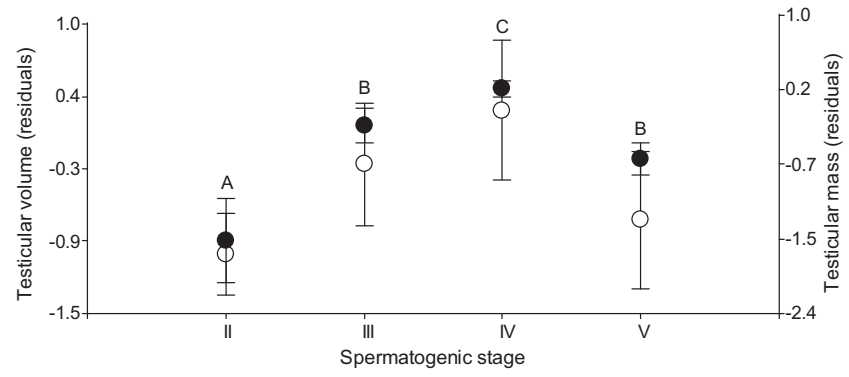

and the Pampa Brazilian biomes (Wiederhecker et al. 2003; Vieira et al. 2011), or the result of intrasexual competition as larger individuals (males, females, or both) temporally displace the reproductive season of the smaller adults (Ruckstuhl and Clutton-Brock 2005; Shine and Wall 2005).

In southern Brazil, offspring from the first clutch of the reproductive season produced by T. torquatus may attain sexual maturity in the same season (Arruda 2009). In Corrientes, hatchlings of T. toquatus present in winter (July) do not reach sexual maturity until the following year (Fig. 12). This delay in maturation is accompanied by greater allocation of energy to growth, increasing fecundity at first reproduction, and being better able to compete for territories and mates in the second year (Olsson et al. 2002; Kohlsdorf et al. 2006).

Mating behaviour was not observed in the field, but our results suggest that mating activity starts in mid-winter (August), when males exhibited spermiogenesis and females present vitellogenic follicles. The simultaneous presence of females with large vitellogenic follicles and oviductal eggs and others with corpora lutea indicates there are at least two clutches per reproductive season. Therefore, females with oviductal eggs in spring can lay a second clutch in summer. Extended mating (through early summer) is likely because we observed sperm production by $80 \%$ of males and the presence of some females with large vitellogenic follicles (up to $10.4 \mathrm{~mm}$ ).

The partial synchrony between male and female gonadal cycles of T. torquatus from Corrientes is typical of most tropidurids
(Table 1), but there is notorious ecotypic variation among species and different populations of the same species in the timing of the reproductive events. In Corrientes, the reproductive season of T. torquatus starts in July and lasts until February, while in the Brazilian Cerrado, it extends from August to February (Wiederhecker et al. 2002), and in the Brazilian Pampa, it is much shorter, lasting from September to January (Arruda 2009). In contrast, in the Brazilian Atlantic Forest, female reproductive cycles vary from seasonal (May-December) in Barra de Maricá (Van Sluys et al. 2010) to continuous in Guriri (Teixeira and Giovanelli 1999).

Different periods of sexual receptivity in small versus large adult females can influence offspring performance and survival. Environmental cues, in particular temperature, photoperiod, and rainfall, not only affect development but also influence the opportunity for feeding and offspring growth (Andrews et al. 2000; Bradshaw and Holzapfel 2007; Du and Shine 2008). For example, the rate of embryonic development is particularly sensitive to the environmental temperatures in oviparous species (Muth 1980; Christian et al. 1986; Van Damme et al. 1992). Incubation period varies among populations of T. torquatus in accordance with temperatures. In Corrientes, with summer mean and maximum temperatures $5{ }^{\circ} \mathrm{C}$ higher than those registered in Brasilia, including the maximum that can exceed $40^{\circ} \mathrm{C}$, incubation lasts about 3 months, while in Alegrete, an extra month of incubation may occur (Arruda 2009), and in Brasília incubation lasts 5 months (Wiederhecker et al. 2002). Temperature has been shown to affect incubation time in other species such as the Common Wall Lizard (Podarcis muralis (Laurenti, 1768)) in which eggs incubated at $24{ }^{\circ} \mathrm{C}$ hatched 5 weeks later than those incubated at 32 and $35^{\circ} \mathrm{C}$ (Van Damme et al. 1992).

In Corrientes, individuals smaller than $40 \mathrm{~mm}$ SVL were observed from early summer (January) to early winter (July; Table 1). These data indicate that the hatching period is the longest among populations of T. torquatus. Overall, the hatching period in tropidurids occurs during summer and autumn, except for the population of T. torquatus from Barra de Maricá where newborns were found in spring (October; Van Sluys et al. 2010; Table 1).

The hatches of the delayed young females of T. torquatus from the Wet Chaco occur in winter when temperatures and rainfall are lower and when fewer arthropods are available (Pocco et al. 2010; Montero et al. 2011). However, although food may be less available during this period, this may be offset by lower predation risk, which could allow lizards to feed more freely. 
Fig. 7. Variation in follicular size of adult female Amazon Lava Lizards (Tropidurus torquatus) throughout the year. NVF, nonvitellogenic follicles (open circles); VF, vitellogenic follicles (solid circles); VFE, vitellogenic follicles and oviductal eggs (asterisks); NVFE, nonvitellogenic follicles and oviductal eggs (shaded squares); VFCL, vitellogenic follicles and corpora lutea (inverted open triangles); WLE, mean between width and length of oviductal eggs (open triangles).

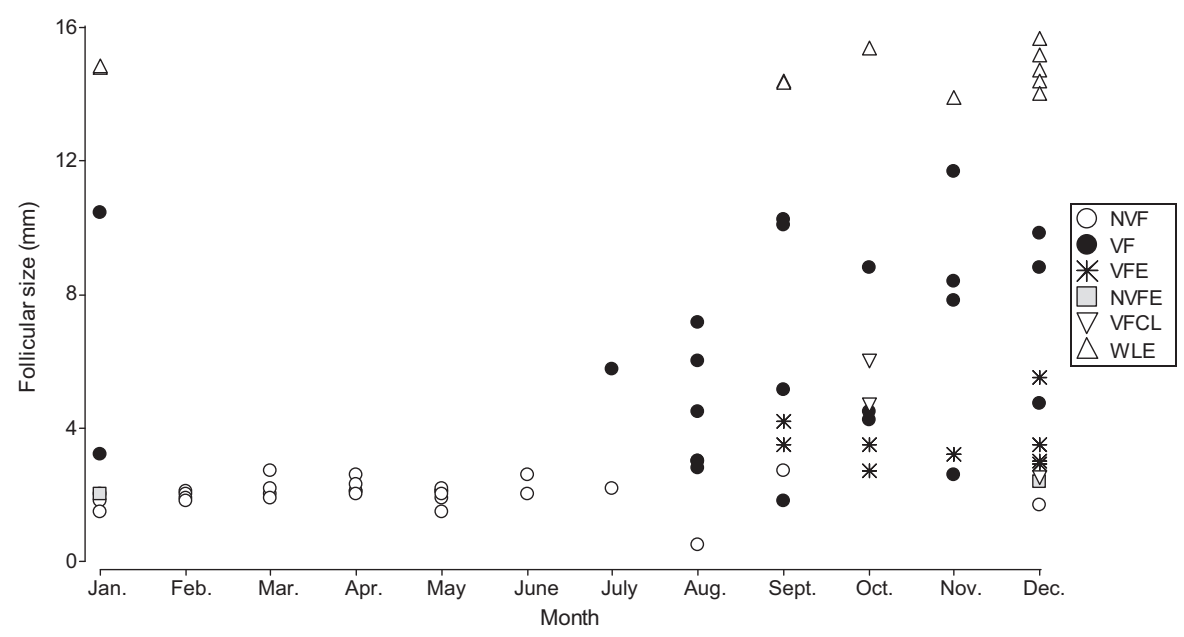

Fig. 8. Female body size distribution (snout-vent length) in the Amazon Lava Lizard (Tropidurus torquatus) based on the reproductive condition throughout the year. NVF, females with nonvitellogenic follicles (open circles); VF, females with vitellogenic follicles (solid circles); VFE, females with vitellogenic follicles and oviductal eggs (asterisks); NVFE, females with oviductal eggs and nonvitellogenic follicles (shaded squares); VFCL, females with vitellogenic follicles and corpora lutea (inverted open triangles).

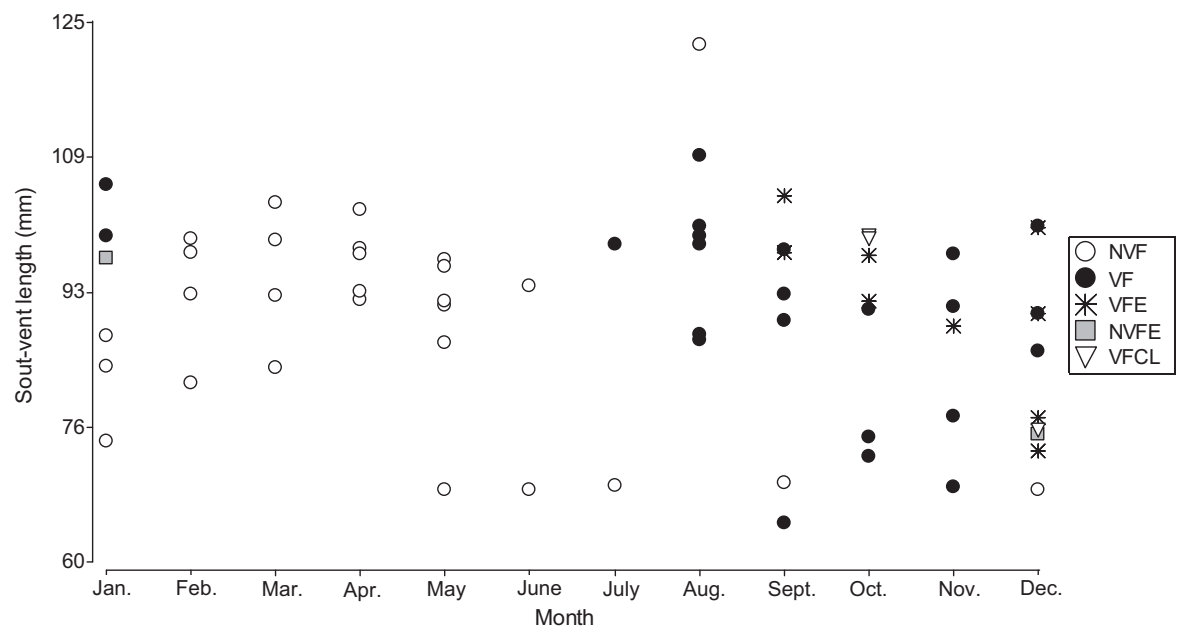

Fig. 9. Relationship between clutch size and snout-vent length in the Amazon Lava Lizard (Tropidurus torquatus).

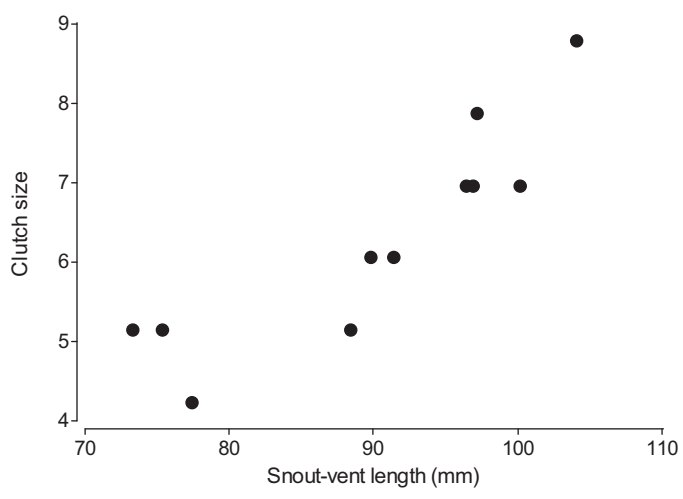

Fig. 10. Relationship between egg volume and snout-vent length in the Amazon Lava Lizard (Tropidurus torquatus).

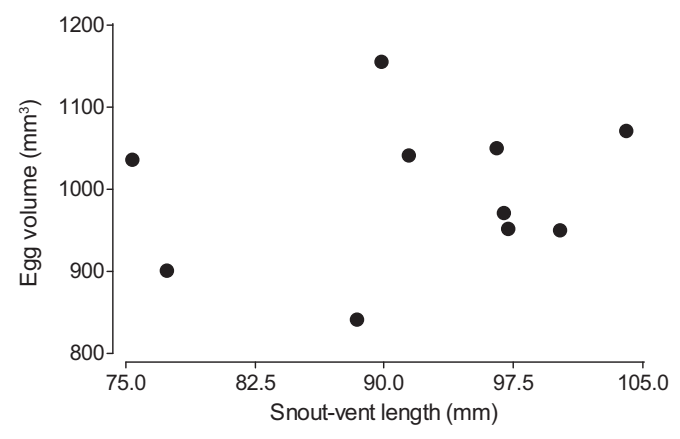


Fig. 11. Fat body annual cycle of adult Amazon Lava Lizards (Tropidurus torquatus). (A) Monthly means of the male residuals obtained from the linear regressions between fat body mass and snout-vent length (open triangles), and between testicular volume and snout-vent length (solid circles). (B) Monthly means of the female residuals obtained from the linear regressions between fat body mass and snout-vent length (open triangles), and mean diameters of the largest follicles (solid circles). Bars indicate the standard error and the different letters indicate significant differences (DGC method, $P<0.05$ ).
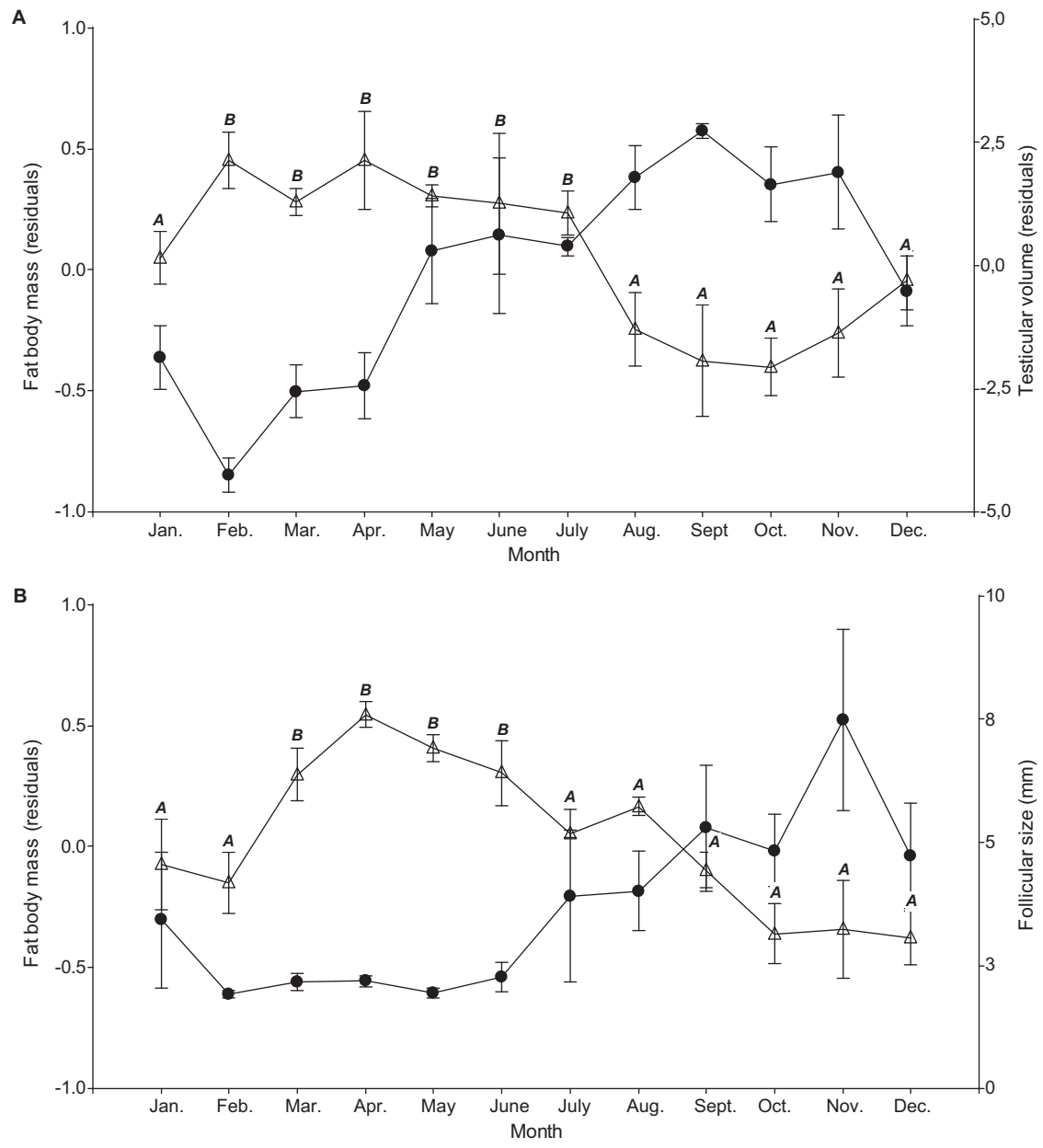

Fig. 12. Body size (snout-vent length) distribution by month in the Amazon Lava Lizard (Tropidurus torquatus): adult males (solid circles): adult females (open circles); juveniles (plus signs).

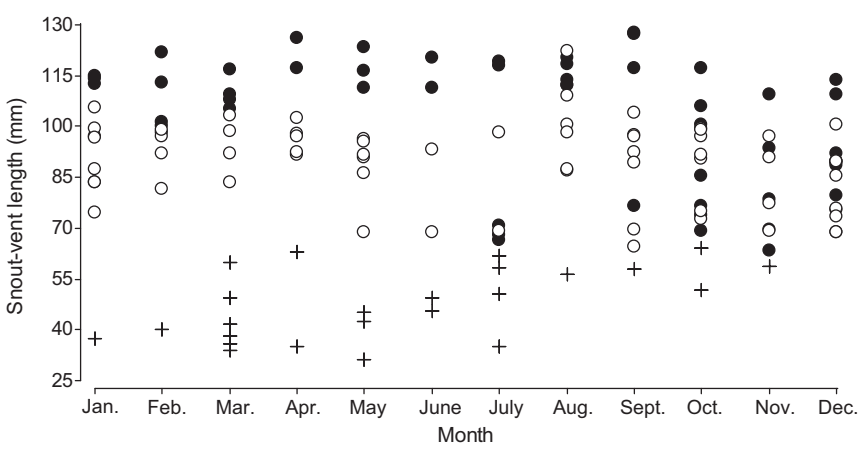

Clutch size, egg size, and clutch frequency can result in a constrained overall reproductive investment (Meiri et al. 2012) and ecotypic variation is expected among T. torquatus populations. Clutch size in the Wet Chaco, Corrientes, is similar to clutches in the Cerrado and Pampa biomes (Arruda 2009; Wiederhecker et al. 2002), while in the Atlantic Forest, clutch size is considerably smaller, consisting of only two eggs (Table 1). In Corrientes, the Cerrado, and the Pampa, the clutch size is correlated with mater- nal SVL (Arruda 2009; Wiederhecker et al. 2002), as is common in tropidurids (e.g., T. itambere: Van Sluys 1993; T. etheridgei: Cruz 1997; Tropidurus montanus: Van Sluys et al. 2002). In Tropidurus populations, selection could favour larger females which would favour greater fecundity even though we did not find a relationship between clutch size and egg size in T. torquatus for Corrientes. The classical theory regarding the size and number of offspring (Smith and Fretwell 1974) predicts that females can produce either a large number of small offspring or fewer large offspring, assuming that a finite amount of energy is allocated into reproduction. When a positive relationship exists between offspring size and fitness, then females that produce larger offspring will be at a selective advantage. Experimental tests have verified this trade-off between egg size and clutch size (Sinervo and Licht 1991; Williams 2001). Nevertheless, this relationship can be affected by female size (Ford and Seigel 1989, 2006), variation in resource acquisition by females (Uller and Olsson 2005), and the number of clutches that are laid per year (clutch frequency; Wang et al. 2011). The effect of clutch frequency may explain the case of $T$. torquatus in the Wet Chaco, as females lay multiple clutches per reproductive season. However, a different strategy was observed in the Atlantic Forest, as clutch size is relatively constrained, perhaps compensated by greater egg size (Van Sluys et al. 2010; Kiefer et al. 2008).

Mean RCM of T. torquatus from Corrientes was similar to the RCM documented for different lizard species $(\mathrm{RCM}=0.255 \pm 0.014$ 
(mean \pm SE), Meiri et al. 2012; $\mathrm{RCM}_{\mathrm{T} \text {. torquatus }}=0.22 \pm 0.04$ (mean \pm $\mathrm{SD})$, present study). Nevertheless, RCM and egg size values of T. torquatus (Corrientes) were the highest reported for the species (Table 1), suggesting a particular selective pressure on females of this population. Vitt and Price (1982) proposed that RCM may vary among populations of a species as a result of differences in food availability or the geographic variation in escape tactics. Tropidurus torquatus is a sit-and-wait predator who relies on its cryptic appearance to avoid predators (Vitt 1981). Therefore, the interpopulation difference in RCM may be due to subtle variations in the prey escape mode in relation to geographical differences related to predator pressures, habitat structure, or availability of shelters and food. These differences allow females to invest more energy in reproduction in localities like Corrientes, even though that could cause a reduction in running speed and therefore a greater risk of predation (Shine 1980).

Inter- or intra-sexual asynchrony is consistent with sexual dimorphism (Emlen and Oring 1977; Kvarnemo and Ahnesjö 1996). Males of T. torquatus from Corrientes are larger in body size and head size than females, which can be beneficial in agonistic encounters (Vitt and Cooper 1985; Anderson and Vitt 1990; Pinto et al. 2005). In fact, sexual selection for increased male body size occurs because of a male-biased OSR resulting from female asynchrony, as the OSR hypothesis predicts (Emlen and Oring 1977; Kvarnemo and Ahnesjö 1996). Larger SVL and head in males have been documented in several tropidurids (Vitt and Goldberg 1983; Vitt 1990, 1993; Perez-Mellado and De la Riva 1993; Van Sluys 1993; Vitt and Zani 1996; Cruz 1997; Cruz et al. 1997; Vitt et al. 1997; Pinto et al 2005; Van Sluys et al. 2002, 2010; Brandt and Navas 2013), suggesting that these differences could have originated early in the evolution of the group (Vitt et al. 1997). Polygynous and territorial behaviours in T. torquatus (Pinto et al. 2005; Kohlsdorf et al. 2006) can explain the sexual dimorphism as a result of sexual selection. However, the relationship between male and female body sizes among tropidurid species is isometric, instead of hyperallometric, as might be expected, which suggests that other factors can also affect size dimorphism (Brandt and Navas 2013).

A longer tail can be advantageous given that dominant males usually execute threat movements with the tail, as well as with the head, warning rival males to avoid combat (Kohlsdorf et al. 2006). However, in spite of males' aggressive interactions, a similar frequency of caudal autotomy was recorded for both sexes in this study which indicates that predation pressure affects males and females in a similar manner. While morphological patterns in male T. torquatus (Corrientes) can be explained by sexual selection, the larger interlimb lengths observed in females are likely an adaptation to allow them to carry a larger clutch (Olsson et al. 2002), which is frequently explained by fecundity selection.

Tropidurus torquatus in Corrientes inhabits a subtropical environment that shows a clear drop in rainfall in winter, and temperature and photoperiod regimes that vary considerably throughout the year. To the extent that variation in climate is predictable, synchrony may develop with reproductive functions. While the testicular parameters in T. torquatus (Corrientes) showed no relationship with the climatic variables, follicular growth in females was associated with change in photoperiod and rainfall in the second half of the year. In tropical environments, rainfall has been noted to be the principal factor that regulates the timing of reproductive activity in female lizards (Sherbrooke 1975; Barbault 1976; Magnusson 1987; Patterson 1991; Rocha 1992). Meanwhile, photoperiod is considered to be the most important variable affecting the reproductive activity in lizard populations from subtropical and temperate regions (Gorman and Licht 1974), probably because it is a reliable sign of seasonality. As suggested by Wiederhecker et al. (2002), the ability to detect environmental signals to predict the arrival of the wet season would be beneficial. Reproduction during the wet season is common in tropidurids (Van Sluys et al. 2010), with the exception of Brazilian populations of T. semitaeniatus in Pernam- buco (Caatinga) and T. torquatus in Barra de Maricá (Atlantic Forest) that reproduce mainly during the dry season (Vitt and Goldberg 1983; Van Sluys et al. 2010). This reproductive pattern has been associated with the higher abundance of arthropods (Rocha 1992, 1996) that coincides with the rainy season (Janzen and Schoener 1968; Buskirk and Buskirk 1976; Wolda 1978; Pinheiro et al. 2002). On the other hand, the rainy season would grant favourable levels of humidity for the proper incubation and development of the eggs (Brown and Shine 2006).

The accumulation of lipids in fat bodies is used as an indicator of food availability (Licht 1974; Derickson 1976; Colli et al. 1997). Both males and females of T. torquatus from Corrientes showed a cyclical pattern of lipid accumulation with the highest values recorded from autumn to early winter, when we should expect a lower arthropod abundance as a consequence of lower temperatures and rainfall. Although this may result in a decrease in arthropod availability, the decrease may not limit the accumulation of lipids. The fat body cycles in both males and females of T. torquatus showed that lipid accumulation reached maximum values when the testicular parameters and follicular sizes reach their minima. However, dissections of specimens suggest that males quickly accumulate lipids in mid-summer that last until winter, while females begin to store lipids in late summer and reach a peak in early autumn, outside the breeding season, and decrease their fat stores markedly in winter (July) when vitellogenesis begins.

Other studies on tropidurids inhabiting highly seasonal environments have registered a seasonal pattern of lipid storage, with increasing lipid stores during the dry season (e.g., T. torquatus: Wiederhecker est al. 2002; T. montanus: Van Sluys et al. 2002; Rodrigues' Lava Lizard, Eurolophosaurus nanuzae: Galdino et al. 2003; T. semitaeniatus and T. hispidus: Ribeiro et al. 2012). According to Colli et al. (1997), the accumulation of lipids during the dry season in sit-and-wait predators, like Tropidurus lizards, derives from a high increment in production efficiency as a consequence of lower maintenance costs. Moreover, a diet study in a population of T. torquatus from Corrientes has demonstrated that there is an increment in food intake during autumn and spring (Álvarez et al. 1985). This bimodal dietary pattern of T. torquatus (Corrientes) coincides with the increase in stored fat in autumn and reproductive activity in spring. Hahn and Tinkle (1965) demonstrated that the accumulation of lipids in fat bodies is crucial for the beginning of the reproductive activity in the Side-blotched Lizard (Uta stansburiana Baird and Girard, 1852). The same is probably true for T. torquatus in Corrientes. However, neither the availability of food nor lipid accumulation in fat bodies seems to be enough to cause reproductive seasonality in this population.

The lengths of the reproductive seasons in T. torquatus from Brasilia (Cerrado biome) (Wiederhecker et al. 2002) and in T. semitaeniatus and T. hispidus from Seridó (Caatinga biome) (Ribeiro et al. 2012) are determined by the lack of appropriate environmental conditions for the development of the eggs during the dry season. Although the rainfall regime is the main limiting factor that explains the reproductive pattern of T. torquatus females from Corrientes, the environmental temperature might be crucial, affecting the seasonal variations in the daily pattern of activity or embryonic development, and therefore, the duration of the reproductive cycle. Arruda (2009) proposed that the seasonality and the extension of the reproductive cycle of T. torquatus from Alegrete (Pampa biome) could be explained by the existence of thermal conditions appropriate for embryonic development.

Females of T. torquatus that inhabit the subtropical environment of Corrientes have an extended 8 month reproductive season and some females probably could lay two clutches per season. 
Table 1. Summary of reproductive characteristics of tropidurid species.

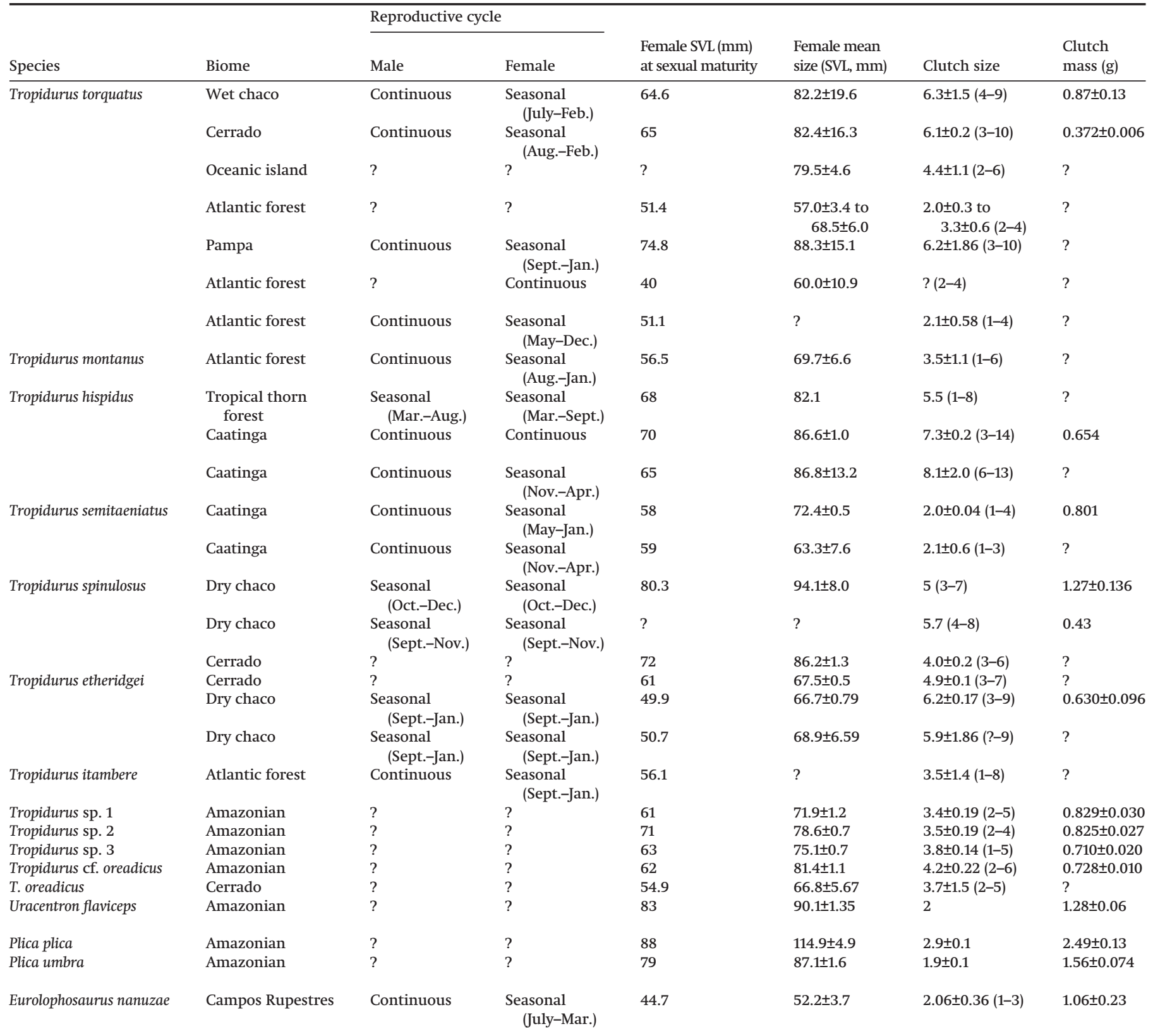

Note: Common name (if available), authority, and year of identification of a species are as follows (order of appearance in table): Amazon Lava Lizard, Tropidurus

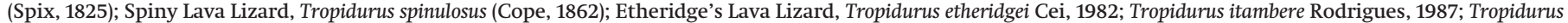

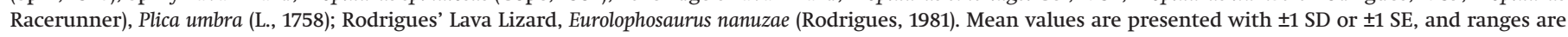

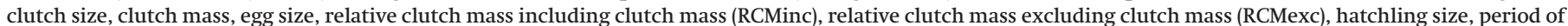

It represents one of the longest seasonal reproductive cycles of the species, except for the Guriri population in the Brazilian Atlantic Forest biome that exhibits continuous reproduction. The comparative analysis performed in the present study provides evidence of variation in the reproductive cycles of males and females and identifies correlates with environmental variables. Other reproductive variables as clutch size, RCM, egg volume, incubation period, hatching time, and the minimum body size for sexual maturity also vary among populations. Such variation could be due to either phenotypic plasticity or ecotypic adaptation to the local environmental conditions or more likely to both. Studies on the role of biotic interactions in spatial distributions under con- trolled laboratory experiments or using reciprocal transplants are needed to test these hypotheses.

\section{Acknowledgements}

We thank R. Aguirre, J.L. Acosta, E. Etchepare, M. Lamas, and S. Palomas for their assistance during the fieldwork, and A.R. Vallejos and M.A. Solis for providing their facilities and technical advice for the histological procedures. This study was supported by a research grant from the Secretaría General de Ciencia y Técnica (SGCyT), the Universidad Nacional del Comahue (CRUB), Consejo Nacional de Investigaciones Científicas y Técnicas (PIP100271, RD2702-12), Agencia Nacional de Promoción Científica y Tecnológica (PICT 1086), and 


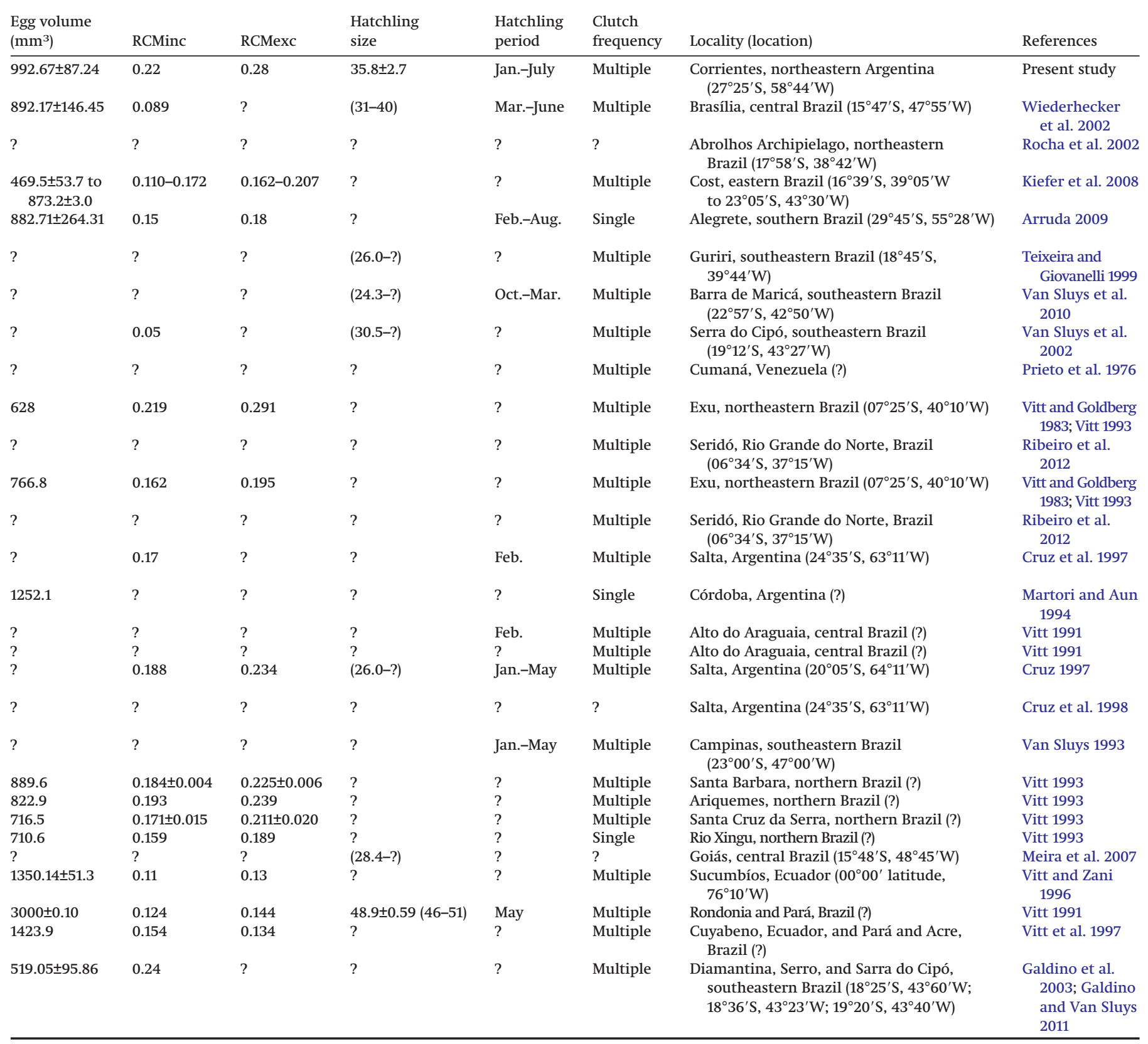

torquatus (Wied-Neuwied, 1820); Tropidurus montanus Rodrigues, 1987; Peters' Lava Lizard, Tropidurus hispidus (Spix, 1825); Striped Lava Lizard, Tropidurus semitaeniatus oreadicus Rodrigues, 1987; Tropical Thornytail Iguana, Uracentron flaviceps (Guichenot, 1855); Tree Runner, Plica plica (L., 1758); Blue-lipped Tree Lizard (or Harlequin presented in parentheses. Question marks represent no data. Shown are comparisons of the reproductive cycle, female body size at maturity, female mean body size, emergence of hatchlings, and clutch frequency (i.e., number of clutches per reproductive season) in different localities and biomes.

MINCyT-CAPES BR11/18). We are grateful to J.D. Krenz and two anonymous reviewers for their critical reviews and their insightful comments of the manuscript. We also thank the Dirección de Fauna of Corrientes for releasing the collecting permits.

\section{References}

Álvarez, B.B., Torales, G., and Tedesco, M.E. 1985. Comportamiento alimentario de una población de Tropidurus torquatus (Iguanidae) del departamento Capital, provincia de Corrientes, Argentina. Historia Natural, 5: 281-288.

Anderson, R.A., and Vitt, L.J. 1990. Sexual selection versus alternative causes of sexual dimorphism in teiid lizards. Oecologia, 84: 145-157.

Andrews, R.M., Mathies, T., and Warner, D.A. 2000. Effect of incubation temperature on morphology, growth, and survival of juvenile Sceloporus undulatus. Herpetol. Monogr. 14: 420-431. doi:10.2307/1467055.
Arruda, J.L.S. 2009. Ecologia de Tropidurus torquatus (Squamata: Tropiduridae) no bioma Pampa, extremo sul do Brasil. M.Sc. thesis, Programa de PósGraduação em Biodiversidade Animal, Universidade Federal de Santa Maria, Santa Maria, RS, Brazil.

Ballinger, R.E. 1977. Reproductive strategies: food availability as a source of proximal variation in a lizard. Ecology, 58: 628-635. doi:10.2307/1939012.

Barbault, R. 1976. Population dynamics and reproductive patterns of three African skinks. Copeia, 1976: 483-490. doi:10.2307/1443363.

Bergallo, H.G., and Rocha, C.F.D. 1993. Activity patterns and body temperatures of two sympatric lizards (Tropidurus torquatus and Cnemidophorus ocellifer) with different foraging tactics in southeastern Brazil. Amphib.-Reptilia, 14: 312315. doi:10.1163/156853893X00525.

Bradshaw, W.E., and Holzapfel, C.M. 2007. Evolution of animal photoperiodism. Annu. Rev. Ecol. Evol. Syst. 38: 1-25. doi:10.1146/annurev.ecolsys.37.091305. 110115. 
Brandt, R., and Navas, C.A. 2011. Life-history evolution on Tropidurinae lizards: influence of lineage, body size and climate. PLoS ONE, 6(5): e20040. doi:10. 1371/journal.pone.0020040. PMID:21603641.

Brandt, R., and Navas, C.A. 2013. Body size variation across climatic gradients and sexual size dimorphism in Tropidurinae lizards. J. Zool. (Lond.), 290: 192-198. doi:10.1111/jzo.12024.

Brown, G.P., and Shine, R. 2006. Why do most tropical animals reproduce seasonally? Testing hypotheses on an Australian snake. Ecology, 87: 133-143. doi:10.1890/04-1882.

Bruniard, E. 1997. Atlas geográfico de la provincia de Corrientes. Tomo I: El medio natural. Geografía 8. Facultad de Humanidades, Universidad Nacional del Nordeste, Resistencia, Chaco, Argentina.

Buskirk, R.E., and Buskirk, W.H. 1976. Changes in arthropod abundance in a highland Costa Rican forest. Am. Midl. Nat. 95: 288-298. doi:10.2307/2424394.

Cabrera, A.L., and Willink, A. 1980. Biogeografía de América Latina. Secr. Gral. O.E.A. Ser. Biol. Monogr. 13: 1-122.

Carnevali, R. 1994. Fitogeografía de la provincia de Corrientes. Cartas, escalas 1:500.000 y 1:1.000.000. Gobierno de la provincia de Corrientes, Instituto Nacional de Tecnología Agropecuaria, Ciudad de Buenos Aires, Argentina.

Carreira, S., Meneghel, M., and Achaval, F. 2005. Reptiles de Uruguay. Dirección de Asuntos Culturales, Facultad de Ciencias, Universidad de la República, Montevideo, Uruguay.

Cei, J.M. 1993. Reptiles del noroeste, nordeste y este de la Argentina. Herpetofauna de las selvas subtropicales, Puna y Pampas. Monografía XIV. Museo Regionale di Scienze Naturali, Torino, Italy.

Christian, K.A., Tracy, C.R., and Porter, W.P. 1986. The effect of cold exposure during incubation of Sceloporus undulatus eggs. Copeia, 1986: 1012-1014. doi: $10.2307 / 1445303$.

Clerke, R.B., and Alford, R.A. 1993. Reproductive biology of four species of tropical Australian lizards and comments on the factors regulating lizard reproductive cycles. J. Herpetol. 27: 400-406. doi:10.2307/1564826.

Colli, G.R., Pérez, A.K., Jr., and Zatz, M.G. 1997. Foraging mode and reproductive seasonality in tropical lizards. J. Herpetol. 31: 490-499. doi:10.2307/1565600.

Cruz, F.B. 1997. Reproductive activity in Tropidurus etheridgei in the semiarid Chaco of Salta, Argentina. J. Herpetol. 31: 444-450. doi:10.2307/1565679.

Cruz, F.B., Teisaire, E., and Nieto, L. 1997. Reproductive biology of the lizard Tropidurus spinulosus in the Chaco of Salta, Argentina. Stud. Neotrop. Fauna Environ. 32: 28-32. doi:10.1076/snfe.32.1.28.13465.

Cruz, F.B., Silva, S., and Scrocchi, G.J. 1998. Ecology of the lizard Tropidurus etheridgei (Squamata: Tropiduridae) from the dry Chaco of Salta, Argentina. Herpetol. Nat. Hist. 6: 23-31.

Derickson, W.K. 1976. Lipid storage and utilization in reptiles. Am. Zool. 16: 711-723. doi:10.1093/icb/16.4.711

Di Rienzo, J.A., Guzmán, A.W., and Casanoves, F. 2002. A multiple-comparisons method based on the distribution of the root node distance of a binary tree. J. Agric. Biol. Environ. Stat. 7: 129-142. doi:10.1198/10857110260141193.

Dixon, J.R., and Soini, P. 1986. The reptiles of the Upper Amazon Basin, Iquitos Region, Peru. Milwaukee Public Museum, Milwaukee, Wisc.

Downes, S.J., and Shine, R. 1999. Do incubation-induced changes in a lizard's phenotype influence its vulnerability to predators? Oecologia, 120: 9-18. doi:10.1007/s004420050827.

Du, W.-G., and Shine, R. 2008. The influence of hydric environments during egg incubation on embryonic heart rates and offspring phenotypes in a scincid lizard (Lampropholis guichenoti). Comp. Biochem. Physiol. Part A Mol. Integr. Physiol. 151: 102-107. doi:10.1016/j.cbpa.2008.06.005.

Duellman, W.E. 1978. The biology of an equatorial herpetofauna. Misc. Publ. Mus. Nat. Hist. Univ. Kans. No. 65.

Dunham, A.E. 1978. Food availability as a proximate factor influencing individual growth rates in the iguanid lizard Sceloporus merriami. Ecology, 59: 770778. doi:10.2307/1938781.

Dunham, A.E. 1982. Demographic and life-history variation among populations of the iguanid lizard Urosaurus ornatus: implications for the study of lifehistory phenomena in lizards. Herpetologica, 38: 208-221.

Dunham, A.E., and Miles, D.B. 1985. Patterns of covariation in life history traits of squamate reptiles: the effects of size and phylogeny reconsidered. Am. Nat. 126: 231-257. doi:10.1086/284411.

Dunham, A.E., Miles, D.B., and Reznick, D.N. 1988. Life history patterns in squamate reptiles. In Biology of the Reptilia. Vol. 16. Ecology B: defense and life history. Edited by C. Gans and R.B. Huey. Alan R. Liss, Inc., New York. pp. 441-522.

Emlen, S.T., and Oring, L.W. 1977. Ecology, sexual selection, and the evolution of mating systems. Science, 197: 215-223. doi:10.1126/science.327542. PMID: 327542 .

Ferreira, A., Kihara, V.O., and Mehanna, M. 2011. Reproductive strategies of Brazilian lizards of the genus Tropidurus Rodrigues, 1987 (Squamata, Tropiduridae) in the temporal and spatial. Int. J. Morphol. 29: 1414-1421. doi:10.4067| S0717-95022011000400058.

Fitch, H.S. 1982. Reproductive cycles in tropical reptiles. Occas. Pap. Mus. Nat. Hist. Univ. Kans. No. 96. pp. 1-53.

Fleming, T.H., and Hooker, R.S. 1975. Anolis cupreus: the response of a lizard to tropical seasonality. Ecology, 56: 1243-1261. doi:10.2307/1934695.

Flemming, A.F. 1993. The male reproductive cycle of the lizard Pseudocordylus m. melanotus (Sauria: Cordylidae). J. Herpetol. 27: 473-478. doi:10.2307/1564842.
Ford, N.B., and Seigel, R.A. 1989. Relationships among body size, clutch size, and egg size in three species of oviparous snakes. Herpetologica, 45: 75-83.

Ford, N.B., and Seigel, R.A. 2006. Intra-individual variation in clutch and offspring size in an oviparous snake. J. Zool. (Lond.), 268: 171-176. doi:10.1111/j. 1469-7998.2005.00006.x.

Galdino, C.A.B., and Van Sluys, M. 2011. Clutch size in the small-sized lizard Eurolophosaurus nanuzae (Tropiduridae): does it vary along the geographic distribution of the species? Iheringia Ser. Zool. 101(1-2): 61-64. doi:10.1590/ S0073-47212011000100008.

Galdino, C.A.B., Assis, V.B., Kiefer, M.C., and Van Sluys, M. 2003. Reproduction and fat body cycle of Eurolophosaurus nanuzae (Sauria: Tropiduridae) from a seasonal montane habitat of southeastern Brazil. J. Herpetol. 37: 687-694. doi:10.1670/114-02A

Gorman, G.C., and Licht, P. 1974. Seasonality in ovarian cycles among tropical Anolis lizards. Ecology, 55: 360-369. doi:10.2307/1935223.

Gribbins, K.M., Elsey, R.M., and Gist, D.H. 2006. Cytological evaluation of the germ cell development strategy within the testis of the American alligator, Alligator mississippiensis. Acta Zool. 87: 59-69. doi:10.1111/j.1463-6395.2006.00220.x.

Guisande, C., Berrio, A., Maneiro, I., Riveiro, I., Vergara, A., and Vaamonde, A. 2006. Tratamiento de datos. Díaz de Santos, Madrid, España.

Hahn, W.E., and Tinkle, D.W. 1965. Fat body cycling and experimental evidence for its adaptive significance to ovarian follicle development in the lizard Uta stansburiana. J. Exp. Zool. 158: 79-85. doi:10.1002/jez.1401580108. PMID: 14299684.

Huang, W.S. 1998. Reproductive cycles of the grass lizard, Takydromus hsuehshanensis, with comments on reproductive patterns of lizards from the central high elevation area of Taiwan. Copeia, 1998: 866-873. doi:10.2307/1447333.

Ibargüengoytía, N.R. 2008. Estrategias reproductivas en reptiles. In Reptiles de Chile. Edited by M. Vidal and A. Labra. Science Verlag, Santiago de Chile. pp. 392-425.

Ibargüengoytía, N.R., and Cussac, V.E. 1998. Reproduction of the viviparous lizards Liolaemus elongatus in the highlands of southern South America: plastic cycles in response to climate? Herpetol. J. 8: 99-105.

James, C., and Shine, R. 1985. The seasonal timing of reproduction: a tropicaltemperate comparison in Australian lizards. Oecologia, 67: 464-474. doi:10. 1007/BF00790016.

Janzen, D.H., and Schoener, T.W. 1968. Differences in insect abundance and diversity between wetter and drier sites during a tropical dry season. Ecology, 49: 96-110. doi:10.2307/1933565

Kiefer, M.C., Van Sluys, M., and Rocha, C.F.D. 2008. Clutch and egg size of the tropical lizard Tropidurus torquatus (Tropiduridae) along its geographic range in coastal eastern Brazil. Can. J. Zool. 86(12): 1376-1388. doi:10.1139/Z08-106.

Kohlsdorf, T., Ribeiro, J.M., and Navas, C.A. 2006. Territory quality and male dominance in Tropidurus torquatus (Squamata, Tropiduridae). Phyllomedusa, 5: 109-118. doi:10.11606/issn.2316-9079.v5i2p109-118.

Kvarnemo, C., and Ahnesjö, I. 1996. The dynamics of operational sex ratios and competition for mates. Trends Ecol. Evol. 11: 404-408. doi:10.1016/01695347(96)10056-2. PMID:21237898.

Licht, P. 1971. Regulation of the annual testis cycle by photoperiod and temperature in the lizard Anolis carolinensis. Ecology, 52: 240-252. doi:10.2307/1934582.

Licht, P. 1973. Influence of temperature and photoperiod on the annual ovarian cycle in the lizard Anolis carolinensis. Copeia, 1973: 465-472. doi:10.2307/ 1443111.

Licht, P. 1974. Response of Anolis lizards to food supplementation in nature. Copeia, 1974: 215-221. doi:10.2307/1443026.

Magnusson, W.E. 1987. Reproductive cycles of teiid lizards in Amazonian Savanna. J. Herpetol. 21: 307-316. doi:10.2307/1563972.

Marion, K.R. 1982. Reproductive cues for gonadal development in temperate reptiles: temperature and photoperiod effects on the testicular cycle of the lizard Sceloporus undulatus. Herpetologica, 38: 26-39.

Martori, R., and Aun, L. 1994. Aspects of the ecology of a population of Tropidurus spinulosus. Amphib.-Reptilia, 15: 317-326. doi:10.1163/156853894X00092.

Mayhew, W.W., and Wright, S.J. 1970. Seasonal changes in testicular histology of three species of the lizard genus Uma. J. Morphol. 130: 163-185. doi:10.1002/ jmor.1051300205.

Meira, K.T.R., Faria, R.G., Silva, M.D.M., de Miranda, V.T., and Zahn-Silva, W. 2007. Natural history of Tropidurus oreadicus in a rocky cerrado area of Central Brazil. Biota Neotrop. 7: 155-163.

Meiri, S., Brown, J.H., and Sibly, R.M. 2012. The ecology of lizard reproductive output. Global Ecol. Biogeogr. 21: 592-602. doi:10.1111/j.1466-8238.2011.00700.x.

Méndez-de la Cruz, F.R., Villagrán-Santa Cruz, M., and Andrews, R.M. 1998. Evolution of viviparity in the lizard genus Sceloporus. Herpetologica, 54: 521-532.

Mesquita, D.O., and Colli, G.R. 2010. Life history patterns in tropical South American lizards. In Reproducción en reptiles: morfología, ecología y evolución. Edited by O. Hernández-Gallegos, F.R. Méndez de la Cruz, and J.F. Méndez-Sánchez. Universidad Autónoma del Estado de México, Estado de México, México. pp. 45-71.

Montero, G.A., Carnevale, N.J., and Magra, G. 2011. Ensambles estacionales de artrópodos epigeos en un bosque de quebracho (Schinopsis balansae) en el Chaco Húmedo. Rev. Colomb. Entomol. 37: 294-304.

Mouton, P.le, Fras, N., Flemming, A.F., and Stanley, E. 2012. Synchronized versus asynchronized breeding in cordylid lizards: an evolutionary perspective. J. Zool. 288: 191-198. doi:10.1111/j.1469-7998.2012.00940.x. 
Muth, A. 1980. Physiological ecology of desert iguana (Dipsosaurus dorsalis) eggs: temperature and water relations. Ecology, 61: 1335-1343. doi:10.2307| 1939042.

Olsson, M., Shine, R., Wapstra, E., Ujvari, B., and Madsen, T. 2002. Sexual dimorphism in lizard body shape: the roles of sexual selection and fecundity selection. Evolution, 56: 1538-1542. doi:10.1111/j.0014-3820.2002.tb01464.x. PMID: 12206252

Patterson, J.W. 1991. Rainfall and reproduction in females of the tropical lizard Mabuya striata striata. Oecologia, 86: 419-423. doi:10.1007/BF00317611.

Perez-Mellado, V., and de la Riva, I. 1993. Sexual size dimorphism and ecology: the case of a tropical lizard, Tropidurus melanopleurus (Sauria: Tropiduridae). Copeia, 1993: 969-976. doi:10.2307/1447074.

Pinheiro, F., Diniz, I.R., Coelho, E., and Bandeira, M.P.S. 2002. Seasonal pattern of insect abundance in the Brazilian cerrado. Austral Ecol. 27:132-136. doi:10. 1046/j.1442-9993.2002.01165.x.

Pinto, A.C.S., Wiederhecker, H.C., and Colli, G.R. 2005. Sexual dimorphism in the Neotropical lizard, Tropidurus torquatus (Squamata, Tropiduridae). Amphib.-Reptilia, 26: 127-137. doi:10.1163/1568538054253384.

Pocco, M.E., Damborsky, M.P., and Cigliano, M.M. 2010. Comunidades de ortópteros (Insecta, Orthoptera) en pastizales del Chaco Oriental Húmedo, Argentina. Anim. Biodivers. Conserv. 33.2: 119-129.

Prieto, A.S., León, J.R., and Lara, O. 1976. Reproduction in the tropical lizard, Tropidurus hispidus (Sauria: Iguanidae). Herpetologica, 32: 318-323.

Ramírez-Bautista, A., and Vitt, L.J. 1997. Reproduction in the lizard Anolis nebulosus (Polychrotidae) from the Pacific coast of Mexico. Herpetologica, 53: 423-431.

Ramírez-Pinilla, M.P. 1995. Reproductive and fat body cycles of the oviparous lizard Liolaemus bitaeniatus (Sauria: Tropiduridae). J. Herpetol. 29: 256-260. doi:10.2307/1564562.

Ribeiro, L.B., Gomides, S.C., Santos, A.O., and Sousa, B.M. 2008. Thermoregulatory behavior of the saxicolous lizard, Tropidurus torquatus (Squamata, Tropiduridae), in a rocky outcrop in Minas Gerais, Brazil. Herpetol. Conserv. Biol. 3: 63-70.

Ribeiro, L.B., Silva, N.B., and Freire, E.M.X. 2012. Reproductive and fat body cycles of Tropidurus hispidus and Tropidurus semitaeniatus (Squamata, Tropiduridae) in a caatinga area of northeastern Brazil. Rev. Chil. Hist. Nat. 85: 307-320. doi:10.4067/S0716-078X2012000300005.

Rocha, C.F.D. 1992. Reproductive and fat body cycles of the tropical sand lizard (Liolaemus lutzae) of southeastern Brazil. J. Herpetol. 26: 17-23. doi:10.2307/ 1565016.

Rocha, C.F.D. 1996. Seasonal shift in lizard diet: the seasonality in food resources affecting the diet of Liolaemus lutzae (Tropiduridae). Cienc. Cult. (Sau Paulo), 48: 264-269.

Rocha, C.F.D., Dutra, G.F., Vrcibradic, D., and Menezes, V.A. 2002. The terrestrial reptile fauna of the Abrolhos archipelago: species list and ecological aspects. Braz. J. Biol. 62: 285-291. doi:10.1590/S1519-69842002000200013. PMID: 12489402.

Rodrigues, M.T. 1987. Sistemática, ecologia e zoogeografia dos Tropidurus do grupo torquatus ao sul do Rio Amazonas (Sauria, Iguanidae). Arq. Zool. (São Paulo), 31: 1-230.

Rodrigues, M.T. 1988. Distribution of lizards of the genus Tropidurus in Brazil (Sauria, Iguanidae). In Proceedings of a Workshop on Neotropical Distribution Patterns, Rio de Janeiro, Brazil, 12-16 January 1987. Edited by P.E. Vanzolini and W.R. Heyer. Academia Brasileira de Ciências, Rio de Janeiro, R.J. pp. 305-315.

Rodríguez-Romero, F., Méndez, F.R., and López-González, L.L. 2005. Análisis comparado del esfuerzo reproductor en algunos lacertilios mexicanos de ambientes tropical y templado. Rev. Soc. Mex. Hist. Nat. 2: 168-177.

Ruckstuhl, K.E., and Clutton-Brock, T.H. 2005. Sexual segregation and the ecology of the two sexes. In Sexual segregation in vertebrates: ecology of the two sexes. Edited by K. Ruckstuhl and P. Neuhaus. Cambridge University Press, Cambridge, UK. pp. 3-7.

Sherbrooke, W.C. 1975. Reproductive cycle of a tropical teiid lizard, Neusticurus ecpleopus Cope, in Peru. Biotropica, 7: 194-207. doi:10.2307/2989623.

Shine, R. 1980. "Cost" of the reproduction in reptiles. Oecologia (Berl.), 46: 92-100. doi:10.1007/BF00346972.

Shine, R., and Wall, M. 2005. Ecological divergence between the sexes in reptiles. In Sexual segregation in vertebrates: ecology of the two sexes. Edited by K. Ruckstuhl and P. Neuhaus. Cambridge University Press, Cambridge, UK. pp. 221-253.

Sinervo, B., and Licht, P. 1991. Proximate constraints on the evolution of egg size, number, and total clutch mass in lizards. Science, 252: 1300-1302. doi:10.1126/ science.252.5010.1300.

Smith, C.C., and Fretwell, S.D. 1974. The optimal balance between size and number of offspring. Am. Nat. 108: 499-506. doi:10.1086/282929.

Stearns, S.C. 1984. The effects of size and phylogeny on patterns of covariation in the life history traits of lizards and snakes. Am. Nat. 123: 56-72. doi:10.1086/ 284186.

Teixeira, R.L., and Giovanelli, M. 1999. Ecologia de Tropidurus torquatus (Sauria: Tropiduridae) da restinga de Guriri, São Mateus, Es. Rev. Brasil. Biol. 59: 11-18.

Uetz, P, and Hošek, J. (Editors). 2013. The reptiles database. Available from http:// www.reptile-database.org [accessed 28 November 2013]
Uller, T., and Olsson, M. 2005. Trade-offs between offspring size and number in the lizard Lacerta vivipara: a comparison between field and laboratory conditions. J. Zool. (Lond.), 265: 295-299. doi:10.1017/S0952836904006326.

Uribe, M.C. 2002. Aparato reproductor masculino. In Atlas de histología de vertebrados. Edited by E. Estrada Flores and M.C. Uribe Aranzábal. Universidad Nacional Autónoma de México, Facultad de Ciencias. pp. 133-148.

Van Damme, R., Bauwens, D., Braña, F., and Verheyen, R.F. 1992. Incubation temperature differentially affects hatching time, egg survival, and hatching performance in the lizard Podarcis muralis. Herpetologica, 48: 220-228.

Van Sluys, M. 1993. The reproductive cycle of Tropidurus itambere (Sauria: Tropiduridae) in southeastern Brazil. J. Herpetol. 27: 28-32. doi:10.2307/1564901.

Van Sluys, M., Mendes, H.M., Assis, V.B., and Kiefer, M.C. 2002. Reproduction of Tropidurus montanus Rodrigues, 1987 (Tropiduridae) a lizard from a seasonal habitat of southeastern Brazil, and a comparison with other Tropidurus species. Herpetol. J. 12: 89-97.

Van Sluys, M., Martelotte, S.B., Kiefer, M.C., and Rocha, C.F.D. 2010. Reproduction in neotropical Tropidurus lizards (Tropiduridae): evaluating the effect of environmental factors on T. torquatus. Amphib.-Reptilia, 31: 117-126. doi:10. 1163/156853810790457920.

Vieira, R.C., Felappi, J.F., Caruccio, R., and Verrastro, L. 2011. Population dynamics of Tropidurus torquatus (Wied, 1820) (Squamata, Tropiduridae) in southern Brazil. S. Am. J. Herpetol. 6: 215-222. doi:10.2994/057.006.0308.

Vitt, L.J. 1981. Lizard reproduction: habitat specificity and constraints on relative clutch mass. Am. Nat. 117: 506-514. doi:10.1086/283731.

Vitt, L.J. 1990. Ecology and life history of the scansorial arboreal lizard Plica plica (Iguanidae) in Amazonian Brazil. Can. J. Zool. 69(2): 504-511. doi:10.1139/z91077.

Vitt, L.J. 1991. An introduction to the ecology of cerrado lizards. J. Herpetol. 25: 79-90. doi:10.2307/1564798.

Vitt, L.J. 1992. Diversity of reproductive strategies among Brazilian lizards and snakes: the significance of lineage and adaptation. In Reproductive biology of South American vertebrates. Edited by W.C. Hamlett. Springer-Verlag, New York. pp. 135-149.

Vitt, L.J. 1993. Ecology of isolated open-formation Tropidurus (Reptilia: Tropiduridae) in Amazonian lowland rain forest. Can. J. Zool. 71(12): 2370-2390. doi:10.1139/z93-333

Vitt, L.J., and Congdon, J.D. 1978. Body shape, reproductive effort, and relative clutch mass in lizards: resolution of a paradox. Am. Nat. 112: 595-608. doi: 10.1086/283300

Vitt, L.J., and Cooper, W.E., Jr. 1985. The evolution of sexual dimorphism in the skink Eumeces laticeps: an example of sexual selection. Can. J. Zool. 63(5): 995-1002. doi:10.1139/z85-148.

Vitt, L.J., and Goldberg, S.R. 1983. Reproductive ecology of two tropical iguanid lizards: Tropidurus torquatus and Platynotus semitaeniatus. Copeia, 1983: 131-141. doi:10.2307/1444707.

Vitt, L.J., and Price, H.J. 1982. Ecological and evolutionary determinants of relative clutch mass in lizards. Herpetologica, 38: 237-255.

Vitt, L.J., and Zani, P.A. 1996. Ecology of the elusive tropical lizard Tropidurus [=Uracentron] flaviceps (Tropiduridae) in lowland rain forest of Ecuador. Herpetologica, 52: 121-132.

Vitt, L.J., Van Lobel Sels, R.C., and Ohmart, R.O. 1978. Lizard reproduction: annual variation and environmental correlates in the iguanid lizard Urosaurus graciosus. Herpetologica, 34: 241-253.

Vitt, L.J., Zani, P.A., and Avila-Pires, T.C.S. 1997. Ecology of the arboreal tropidurid lizard Tropidurus (= Plica) umbra in the Amazon region. Can. J. Zool. 75(11): 1876-1882. doi:10.1139/z97-817.

Wang, Z., Xia, Y., and Ji, X. 2011. Clutch frequency affects the offspring sizenumber trade-off in lizards. PLoS ONE, 6(1): e16585. doi:10.1371/journal.pone. 0016585. PMID:21305034.

Watling, J.I., Waddle, J.H., Kizirian, D., and Donnelly, M.A. 2005. Reproductive phenology of three lizard species in Costa Rica, with comments on seasonal reproduction of neotropical lizards. J. Herpetol. 39: 341-348. doi:10.1670/8002A.1.

Wiederhecker, H.C., Pinto, A.C.S., and Colli, G.R. 2002. Reproductive ecology of Tropidurus torquatus (Squamata: Tropiduridae) in the highly seasonal Cerrado biome of central Brazil. J. Herpetol. 36: 82-91. doi:10.2307/1565806.

Wiederhecker, H.C., Pinto, A.C.S., Paiva, M.S., and Colli, G.R. 2003. The demography of the lizard Tropidurus torquatus (Squamata, Tropiduridae) in a highly seasonal Neotropical savanna. Phyllomedusa, 2: 9-19. doi:10.11606/issn.23169079.v2i1p09-19.

Wilhoft, D.C. 1963. Reproduction in the tropical Australian Skink, Leiolopisma rhomboidalis. Am. Midl. Nat. 70: 442-461. doi:10.2307/2423068.

Williams, T.D. 2001. Experimental manipulation of female reproduction reveals an intraspecific egg size-clutch size trade-off. Proc. R. Soc. Lond. B Biol. Sci. 268: 423-428. doi:10.1098/rspb.2000.1374.

Winck, G.R., and Rocha, C.F.D. 2012. Reproductive trends of Brazilian lizards (Reptilia, Squamata): the relationship between clutch size and body size in females. North-West. J. Zool. 8: 57-62.

Wolda, H. 1978. Seasonal fluctuations in rainfall, food and abundance of tropical Insects. J. Anim. Ecol. 47: 369-381. doi:10.2307/3789.

Zuur, A.F., Ieno, E.N., and Elphick, C.S. 2010. A protocol for data exploration to avoid common statistical problems. Methods Ecol. Evol. 1: 3-14. doi:10.1111/j. 2041-210X.2009.00001.x. 